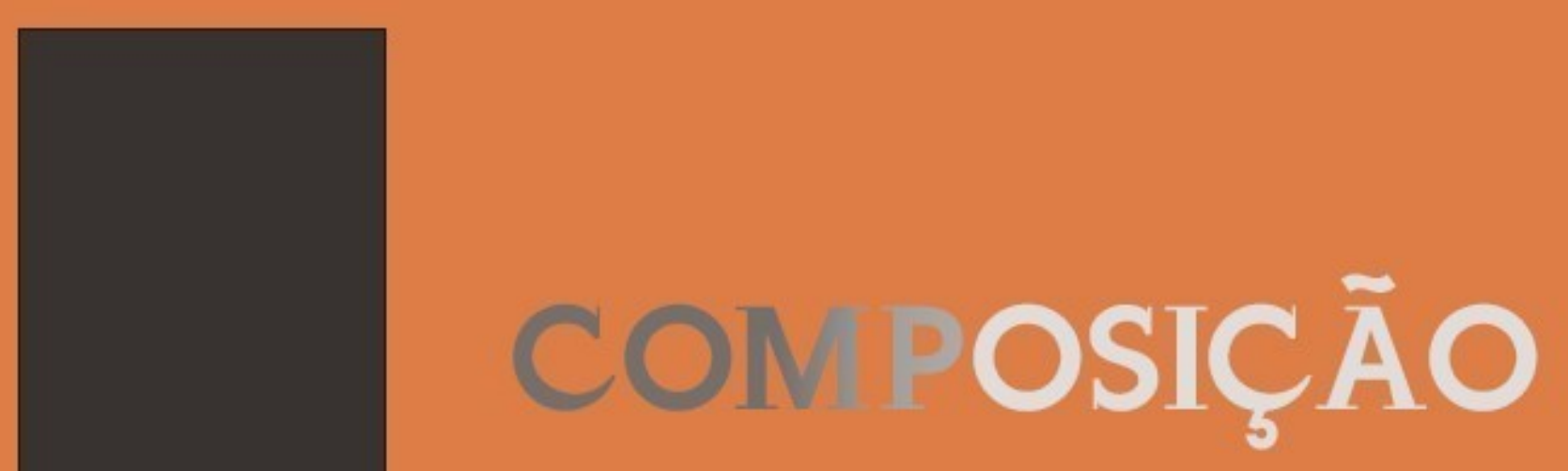

\title{
Revista de Ciências Sociais
}

Universidade Federal de Mato Grosso do Sul

v 2, n 25 Julho-dezembro de 2021 https://doi.org/10.36066/compcs.v2i25

ISSN: 1983-3784 


\section{EDITORIAL}

Doi:https://doi.org/10.36066/compcs.v2i25.15155

Composição, Revista de Ciências Sociais da Universidade Federal de Mato Grosso do Sul, chega a sua edição de número 25 do volume 2, correspondente aos meses de julho a dezembro de 2021. Nesta edição, Composição traz contribuições de pesquisadores São Paulo, Rio Grande do Sul, Paraíba e de outros estados como São Paulo, Rio de Janeiro e Rio Grande do Sul, representando centros de pesquisa de renomadas universidades brasileiras, como USP, UFRGS e outras, variando a temática em desenvolvimento regional, relações raciais, direitos humanos e psicologia das massas.

Continuamos recebendo colaborações em fluxo contínuo para as próximas edições, submeta seu artigo, tradução, resenha ou entrevista com autoridade acadêmica reconhecida na área de ciências sociais. Os textos podem ser em português, inglês, espanhol ou francês. Boa leitura.

Prof. Dr. Aparecido Francisco dos Reis - Editor 


\section{SUMÁRIO}

Doi: https://doi.org/10.36066/compcs.v2i25.15227

\section{RESENHA}

O problema da linha de cor e a diferença cultural: raça, etnicidade e diáspora no século XXI

Hasani Elioterio dos Santos.

. $3-12$

\section{ARTIGOS}

1- DESENVOLVIMENTO REGIONAL: Reflexões sobre o caso da SUDENE

Annahid Burnett; Pedro Maranhão.

2-A produção do legislativo brasileiro acerca da Convenção americana de Direitos Humanos

Marcírio Barcellos Gessinger. $.30-43$

3-O ânimo das massas e a psicologia do sujeito mutilado: Leon Trotsky e Theodor Adorno sobre o fascismo e a extrema direita

Lucas Fiaschetti Estevez. $.44-55$ 


\section{O problema da linha de cor e a diferença cultural: raça, etnicidade e diáspora no século XXI.}

\section{The problem of color line and the cultural difference: race, ethnicity and diaspora in the 21 st century.}

Resenha do livro: HALL, Stuart. The Fateful Triangle: Race, Ethnicity and Nation. Cambridge, Massachusetts, London: Harvard University Press, 2017.

$$
\text { Hasani Elioterio dos Santos }{ }^{1}
$$

Recebido em 17/02/2021, aceito em 05/01/2022

Em The Fateful Triangle (2017) Stuart Hall discute assuntos centrais sobre a formação da modernidade e contemporaneidade. Boa parte da estratégia de argumentação de Hall no livro se dá à luz de importantes categorias de análise frequentes nos enredos políticos da história da modernidade como "raça", "etnicidade" e "nacionalidade", tendo em vista suas correlações com a produção discursiva da noção de diferença. The Fateful Triangle faz parte de uma série de publicações da Universidade de Harvard baseadas em palestras (lectures) conferidas por especialistas de diversas áreas do conhecimento sobre temas explorados e tangenciados pelo sociólogo W.E.B. Du Bois - as W.E.B Du Bois Lectures organizada pelo professor Henry Louis Gates Jr.

No prefácio Henry Louis Gates Jr argumenta que a ideia de raça como uma categoria que indica diferença biológica é tão antiga quanto o encontro europeu com as outras civilizações no século XVI. Para ele, a noção de fusão entre diferença fenotípica e cultural constantemente se justapõe com o desejo econômico e a exploração colonial, produzindo o imaginário simbólico do africano como um significante negativo. Deste modo, a categoria raça em vários casos pode ser vista como um amálgama de etnicidade, religião e nacionalidade, ou de uma maneira que venha cada um destes componentes separadamente.

Dentro desse panorama o que intriga o professor Henry Louis Gates Jr na obra de Stuart Hall é a forma que grupos que passam pela experiência da opressão e subalternização atuam em direção à autorrealização e libertação, invertendo essas categorias sem descartá-las de vez, ao

\footnotetext{
${ }^{1}$ Doutorando do Programa de Pós Graduação em Sociologia da Universidade Federal de São Carlos (PPGS/UFSCar), bolsista CAPES. E-mail: hasanisantos@gmail.com; (11) 995016991. Rod. Washington Luiz, s/n Monjolinho, São Carlos - SP, 13565-905
} 
invés de encampar um suposto orgulho racial ou étnico com efeitos de essencialização e fixidez. Para Hall, nós vivemos em um mundo de misturas e migrações, e neste contexto as fronteiras das noções de raça, etnicidade e nacionalidade são fundamentais para entender os significantes de diferença cultural.

A noção de diferença em Stuart Hall é baseada na difference do pós-estruturalismo de Derrida. Ela não diz respeito tão somente a uma diferença pura e simplesmente operacionalizada por uma oposição entre unidades espelhadas, mas sim em termos de uma articulação, ou diferença que defere. Neste sentido, ao trabalharmos com a obra de Hall, temos sempre em vista as formas criativas que grupos e indivíduos marginalizados criam identificações e posicionalidades em uma determinada conjuntura histórica criando uma experiência histórica compartilhada contextual.

Em outras palavras, significa dizer que um dos objetivos de Hall neste brilhante livro é de complicar e perturbar nossas noções, ainda tão persistentes em nossa gramática de convívio social, de raça, etnicidade e nação - a qual ele chama de fateful triangle. A partir desse objetivo crítico ele propõe para os(as) leitores(as) um campo de novas possibilidades para pensarmos nossas noções de pertencimento e os momentos históricos que caracterizam os processos de identificação .

Henry Louis Gates Jr também discorre sobre alguns problemas referentes às interpretações equivocadas da obra de Hall, mencionando que muitas vezes seus escritos sobre raça e cultura são pensados como discursos paralelos, quando na realidade são inextricáveis e conectados, partes componentes de um mesmo pensamento crítico sobre o mundo em que vivemos. Para desmistificar as interpretações que ele julga problemáticas, Henry Louis Gates Jr enumera brevemente algumas das iniciativas e ações que Stuart Hall esteve presente como teórico e organizador.

Durante o fim dos anos 80 Hall esteve à frente da Association of Black Photographers (ABP), ou simplesmente $\underline{\text { Autograph}}$. Nos anos 90 Hall organizou o Institute of International Visual Arts (Iniva). Ambas as organizações têm grande impacto na produção de conteúdo artístico e visual de caráter crítico no Reino Unido e tocam em temas como os impactos da globalização e a migração. A produção teórica de Stuart Hall influenciou importantes artistas 
como Isaac Julien e John Akomfrah e curadores de arte como David A. Bailey, Mark Sealy e Renée Mussai. Além deste movimento artístico negro no interior do Reino Unido, Hall influenciou posteriores produções teóricas de intelectuais contemporâneos renomados como Hazel V. Carby, Kobena Mercer e Paul Gilroy.

Enquanto leitor eu me detive profundamente nestas informações presentes no rico prefácio do livro. Essa passagem me provocou e levou a uma reflexão que julgo pertinente de ser feita nesta resenha, digo particularmente sobre a semelhança entre W.E.B. Du Bois e Stuart Hall. Essa semelhança foi apontada outrora por Les Back e Maggie Tate (2018) em um artigo em que os autores dizem que Stuart Hall é tido como o "Du Bois da Grã-Bretanha"2. Dialogando com eles vejo que um ponto relacional entre Du Bois e Hall, que é justamente a capacidade dos dois de serem intelectuais públicos, organizarem e articularem a produção de conhecimento científico com movimentos artísticos pontuais e específicos que demarcam historicamente a ação da cultura política negra da diáspora de forma criativa.

No caso de Du Bois há uma relação de parte de sua produção teórica e suas proposições e objetivos políticos de conceber a arte como um campo estratégico de produção discursiva em uma perspectiva modernista. Em dois textos, em particular, The Souls of Black Folk (1903) e The Negro Minds Reach Out (1924) ele dá devida atenção para a importância da produção cultural negra e sua capacidade de forjar e criar comunidade por meio de um comprometimento existencial com a "dupla consciência"”.

Du Bois foi responsável direto na fomentação do fértil movimento artístico que se deu na década de 1920 nos EUA, chamado Harlem Renaissance, um intenso e rico movimento artístico que contou com inúmeros participantes como Malvin Gray Johnson, Aaron Douglas, Louis Mailou Jones, Elizabeth Catlett, dentre outros e outras. Tanto Du Bois, como o filósofo Alain Locke e a antropóloga Zora Neale Hurston foram alguns dos teóricos responsáveis por essa "bomba cultural" negra que explodiu em pleno Harlem no período posterior a I Guerra Mundial.

\footnotetext{
${ }^{2} \mathrm{Na}$ realidade essa afirmação foi feita pelo professor Henry Louis Gates Jr., nos dias após a morte de Stuart Hall em 10 de fevereiro de 2014. Les Back e Maggie Tate (2018) relembram dessa afirmação e estruturam o argumento do artigo em torno dessa ideia.

3 A ideia de "dupla consciência" em Du Bois refere-se a difícil e conflituosa convivência entre o pertencimento branco e o não-branco, uma vez que o processo de formação subjetiva racializada se dá tendo o polo branco como eixo orientador o negro se vê como tal em função da perspectiva e forma de olhar branca. Trata-se de uma noção que retrata a luta em torno do pertencimento travada no interior do corpo negro.
} 
Essa informação - sobre a importância de Du Bois para o Harlem Renaissance e de Stuart Hall para a produção fotográfica e cinematográfica de migrantes caribenhos, africanos e asiáticos no Reino Unido (ABP e Iniva) - é um tema que de fato me chama atenção e corrobora ainda mais com os argumentos apresentados por Les Back e Maggie Tate (2018). Isso significa que a existência de diálogos e consonância entre as práticas e produções de Du Bois e Stuart Hall é identificável, principalmente a respeito de como os dois concebiam os movimentos artísticos que ambos faziam parte, integravam e organizavam.

Essas informações nos possibilitam ver que a produção cultural, e a cultura - seu campo maior de disputa e luta por hegemonia - é um elemento central das formulações e proposições dos dois autores. Ambos representam o pensamento e o sistema de circulação de ideias da intelectualidade negra em escala transnacional. E personificam em suas trajetórias a quebra de paradigma discutida por Gilroy (1993) em Black Atlantic sobre como cultura e política, assim como estética e ética não estão deslocados, ou separados no interior do pensamento e da produção cultural e teórica do Atlântico Negro.

Isso reflete no modelo de coexistência entre poiésis e poética nessa estrutura rizomática, identificada por Paul Gilroy como Atlântico Negro - que é um modelo de possibilidade interpretativa sobre as produções culturais e a teoria social negra em conjunto - que desrespeita as noções da modernidade iluminista de divisão entre o cultural e o político. Para boa parte dos pensadores do Atlântico Negro, agir culturalmente é interferir politicamente de forma simultânea. Du Bois e Stuart Hall representam de maneira admirável essa premissa.

As reflexões de Stuart Hall estão de fato orientadas a uma forma de se pensar relacionalmente e contextualmente. Para Hall tanto a cultura como a política são práticas sem garantias, e isso é estendido para suas noções de raça, etnicidade e nacionalidade. Por mais que sejam ideias que aparentam ser permanentes, perseverantes e imutáveis em termos de convívio social, elas se alteram, transformam e se modificam ao longo dos eixos tempo e espaço.

Em Fateful Triangle há certamente uma discussão sobre estas categorias que se interligam e entrecruzam nos processos sociais da vida real e cotidiana. Stuart Hall ao fazer uma análise crítica sobre a produção de diferença cultural nos mostra que estas categorias são três formas de representar discursivamente a noção de diferença e produzir historicamente relações de poder ao longo do período que classificamos como modernidade. Hall aponta para a agência da noção de diferença na operacionalização discursiva e política da realidade social. 
Nestes termos Hall atualiza o conhecido diagnóstico sociológico de Du Bois sobre o problema do século XX - o problema da linha de cor $(\underline{\text { color line }})^{4}$ - que para Hall é visto pela ótica do século XXI e o problema de se conviver com a diferença. Essa atualização do pensamento duboisiano não é somente um apontamento análogo sobre o problema da color line apresentado por $\mathrm{Du}$ Bois no início do século $\mathrm{XX}$, é, sobretudo, uma transformação historicamente específica e contextual dessa formulação nos termos de diferença cultural.

O primeiro capítulo do livro se chama "Raça - significante deslizante" e disserta sobre as formas que a categoria raça, em sua perspectiva biológica, se mostra aparentemente como uma ideia perene no tempo e no espaço, apesar de toda uma série de esforços feitos para mostrar que seu caráter não é biológico, mas sim sociológico e histórico. A raça é uma categoria que não tem nenhuma validade científica que respalde sua relevância na biologia, porém diante da força das produções discursivas sobre a diferença revelam-se toda uma disputa em torno dos recursos simbólicos da categoria raça e sua possibilidade de dar sentido às condições da vida social de grupos e indivíduos.

Daí sua importância como categoria sócio-histórica e não biológica, tendo em vista uma série de comprovações científicas que desmentem a perspectiva biológica do termo ${ }^{5}$. Raça, nesse sentido, é uma construção sócio-histórica e sua característica é o fato de ser um significante deslizante que adquire, em determinados contextos e situações históricas, características e configurações específicas. Tais características, nós enquanto analistas podemos capturar dando visibilidade às políticas discursivas que giram em torno desse significante e as cadeias de equivalências produzidas pela articulação de semelhanças e diferenças.

O segundo capítulo "Etnicidade e Diferença em tempos globais" inicia com um debate sobre os discursos fechados da etnicidade e seus rumos para um caminho que leva para o "tudo ou nada" essencialista, este que versa a respeito de uma etnicidade natural imutável, assim como a perspectiva biologizante (sem validade científica) sobre o termo raça. Deste modo, Hall faz uma leitura crítica anti-essencialista da ideia de raça e etnicidade. Um dos eixos de análise que estão presentes no livro é a atenção que Hall dá para os problemas que concernem aos discursos

\footnotetext{
${ }^{4}$ Linha de Cor, ou Color Line é pensada por Du Bois como uma estrutura global que configura estratificações e hierarquizações sociais por meio dos usos políticos da categoria "raça". As "raças", portanto, são categorias sociológicas e políticas e não biológicas que foram úteis à formação dos impérios ocidentais e da manutenção do colonialismo. A Linha de Cor é entendida como uma estrutura global de opressão e estratificação social.

${ }^{5}$ Como a descoberta do DNA em 1953, ou o caso de Henrietta Lacks dois anos antes, em 1951, por exemplo.
} 
fechados sobre raça, etnicidade e nação e sua produção de uma closura (fechamento) de um grupo, o que acaba limitando nossa perspectiva histórica a respeito destes termos.

Neste capítulo Hall fala do solo contraditório - sobre qual o impacto da globalização, a migração e a desigual multiculturalização da vida cotidiana está emergindo - como um terreno contemporâneo do conflito cultural. Trata-se do retorno da etnicidade como um significante deslizante e ambivalente nas políticas culturais da diferença que caracteriza nosso momento global. Os efeitos desse retorno das etnicidades são o deslocamento do universalismo do iluminismo e a subsequente re-valorização da diferença entre os movimentos sociais.

Hall se propõe a deslocar o conceito de etnicidade (para além de seu deslocamento de um pólo negativo para o positivo, e a reavaliação dos significantes de diferença) para desconstruir o que ele alega ser a sua sedução desarmante. Para ele a etnicidade é como a face de Jano - duas caras - contraditória e que desliza características da cultura na natureza e vice-versa ${ }^{6}$. A questão para Hall é que estamos sempre negociando posicionalidades.

Isso nos leva a pensar que a identidade cultural é sempre específica, fundamentada através da indicação/marcação de similaridade e diferença. A identificação é um processo de marcação discursiva que dá a cada identidade cultural suas histórias e linguagens. Essas condições de identificação têm sempre efeitos reais, materiais e simbólicos. As identidades culturais são pontos de identificação ou sutura, feitas dentro dos discursos da história e cultura para posicionar o sujeito em relação às suas noções de passado (que é sempre uma questão discursiva). Portanto, para ele as identidades culturais importam, não porque nos fixa em um lugar politicamente, mas porque elas estão sempre em jogo e negociação. São elas que nós temos a ganhar e perder em termos de políticas culturais.

A partir desta perspectiva crítica Hall elabora uma proposição dando visibilidade às "novas etnicidades". Esta proposta é representada e reproduzida em algumas manifestações artísticas que não estão preocupadas em eternizar uma identidade em mitos de pureza e origem e que não se desdobram em formas exclusionárias e fechadas de lidar com a diferença. A aposta de Hall é nas modalidades de identificação coletiva sujeitas a condições históricas que passam diante de nossos olhos e percorrem nossas vidas, trata-se de um posicionamento contextual e estratégico.

\footnotetext{
${ }^{6} \mathrm{Na}$ mitologia Romana Jano (ou Janus em Latim) é uma deidade das mudanças, ele é representado por um homem com duas faces olhando para direções opostas, frente e verso.
} 
Essa sua perspectiva é um ponto de diálogo que nos liga com o terceiro capítulo do livro "Nações e Diáspora". O ponto de partida do autor neste capítulo são as formações da diáspora a qual a história do Caribe está fundamentada, conjuntamente com os elementos ameríndios (ou americanos), europeus e africanos. Esses elementos são pensados por Hall como "presenças culturais" que se manifestam nas relações sociais das ilhas que constituem a região do Caribe. Todas essas presenças são rearticuladas em novas configurações que representam o paradigma expresso pelo termo diáspora.

A diáspora não é uma perda trágica de uma origem, raiz (ㅁoots). Ela é uma rede polissêmica e dissonante de entrecruzamentos culturais (ㅁoutes). São essas rotas de entrecruzamentos culturais que dão o caráter dinâmico e inovador de um período marcado por diálogos transnacionais, seja em termos culturais, políticos ou econômicos, que para Hall operam como esferas da vida social que são trabalhadas e articuladas conjuntamente.

A questão da nação é um ponto importante de análise do autor, pois para ele as nações não emergem pura e simplesmente, elas são forjadas e formadas. Nação é uma comunidade simbólica, suas dimensões têm em vista a produção de poder que gera identidade e aliança. E dentro da gramática de convívio social no Estado-Nação todo discurso sobre identidade é feito pela e através da diferença e sua articulação com o "eu" e o "outro". As identidades nacionais da modernidade articulam política e cultura - duas metades da equação nacional para Hall.

A sociologia de Stuart Hall é marcada por essa perspectiva de ver a sociedade e suas instâncias constitutivas de um modo que estejam sempre abertas para as contingências históricas. Tais contingências são sensíveis aos processos culturais, nesse sentido é relevante atribuir a Hall a característica de conferir à cultura uma importância para lidar com processos históricos e sociais marcados por disputas políticas. Para o Centro de Estudos Culturais Contemporâneos de Birmingham $^{7}$ a cultura é um elemento chave para entender as mudanças sociais que passamos. É na instância cultural que enquanto analistas dos processos sociais podemos ver as disputas de forças emergentes na tentativa de fazerem valer suas presenças em termos de hegemonia.

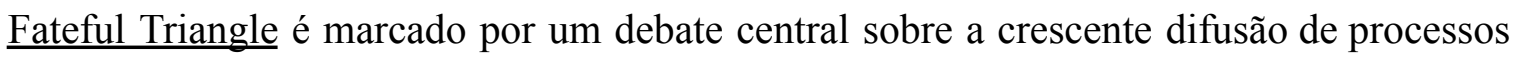
de antagonização em termos de diferença cultural. Para Hall este é um dos desafios de nossos

\footnotetext{
${ }^{7}$ Centro de Estudos Culturais Contemporâneos, na Universidade de Birmingham, é o grupo que Stuart Hall esteve filiado desde 1964, quando este recebeu o convite de Richard Hoggart para participar. Mais tarde Hall tornou-se diretor deste centro de estudos e pesquisas.
} 
tempos. É por esse motivo que vemos que a noção de contradição em nosso presente momento está articulada com lutas em torno das diferenças e dos processos de identificação, ou seja, em termos de experiência de pertencimento coletivo - codificado no livro em termos de raça, etnicidade e nação - que compõe grande parte deste nosso panorama de disputas e conflitos políticos.

Um exemplo claro citado por Kobena Mercer (2017, p. 21) na introdução do livro é a atenção que Hall dá à proliferação de identidades hifenizadas como, franco-argelinos(as); turco-germânicos(as); afro-americanos(as); latino-americanos(as); afro-brasileiros(as); afro-canadenses; inclusive os afro-caribenhos(as), cuja tradição intelectual é pensada pelo próprio Stuart Hall e por Borda (2018), através da ideia de "prisma de formação caribenha".

Esse prisma de formação de pensamento é a metáfora do deslocamento feito por autores(as) afro-caribenhos(as), como por exemplo, Oliver Cox, C.L.R. James, George Padmore, Sylvia Wynter, Frantz Fanon, dentre outros(as). Assim como a ideia do prisma que desloca e articula feixes de luz, a noção dos deslocamentos e trajetórias destes autores representa a fuga, ou deslocamento de perspectivas teóricas e culturais. Essa tradição de pensamento intelectual afro-caribenha pode ser vista como uma expressão particular de uma problemática global e mais ampla (BORDA, 2018, p. 57).

O prisma de formação de pensamento afro-caribenho adquire a característica de uma "consciência oposicional" que é produto direto da experiência de circulação e trajetória desses(as) autores(as) e suas experiências com diferentes gramáticas do processo de racialização nos grandes centros metropolitanos e imperiais. Para Borda (2018) a tradição de pensamento afro-caribenha, lida na chave do prisma, oferece uma possibilidade, uma janela de fuga da zona do não-ser (na perspectiva fanoniana), ou uma fuga do nível abaixo da linha de cor (em termos duboisianos).

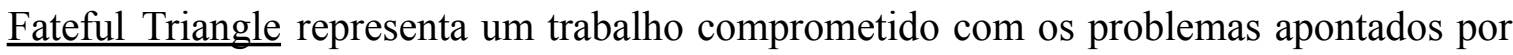
uma tradição de pensamento, está presente em Du Bois e em Fanon, e os articula à luz de alguns eventos do fim do século XX e início do século XXI na chave da diferença cultural. A globalização é um fato que perpassa todo o livro. Para Hall o processo de globalização fraturou as coordenadas temporais e espaciais de nossos sistemas de representação para as noções de identidade cultural e comunidade imaginada (pertencimento). 
Atualmente no século XXI vivemos um momento em que o fluxo cultural e os laços coletivos estão operando acima e abaixo do nível do Estado-Nação, funcionando como escalas interpenetrantes que causam uma disrupção nas distinções convencionais de vizinhança e região. Um dos objetos de pesquisa de Hall neste trabalho é visibilizar este aspecto impressionante das novas formas de globalização, ao lado das tendências de homogeneização há também a proliferação da diferença em todas as suas formas.

A globalização no século XXI é um processo desigual, com efeitos dramáticos e diferentes em diversos locais. O fato é que desde a colonização tempos e espaços diferentes nunca coexistiram pacificamente, mas foram na realidade truncados e condensados dentro de um cronótopo dominante, abstrato e imperial que é o tempo ocidental. A ideia de que as periferias coloniais são espaços fechados, etnicamente puras, culturalmente tradicionais e eternamente imperturbáveis é meramente uma fantasia sobre o outro. Nesse sentido, um dos perigos da globalização é sua disseminação das narrativas homogeneizantes.

Encaminhando esta resenha para o fim, há uma passagem que considero interessante sobre os efeitos da globalização. Refiro-me ao que Hall chama de "crise de identidade", identificada por ele nos anos 50-60 na Grã Bretanha, e que advém das grandes migrações e a mudança da geopolítica imperial em torno dos EUA como o novo império insurgente após a II Guerra Mundial. As migrações em massa, por exemplo, deslizam essa equação simplificada de que um povo equivale a um etnos sob o mesmo "teto homogêneo". Para Hall há uma característica de contradição na migração - ela proporcionou o desenho do que concebemos como modernidade e desafia a própria modernidade (suas fronteiras de Estado-Nação). O recuo da antiga noção de Estado-Nação é uma grande questão presente no fim do século XX.

No entanto há sua contraofensiva - a restauração conservadora de um absolutismo étnico para pavimentar novas histórias de identidade cultural. O Fundamentalismo (seja em sua perspectiva ocidental ou não ocidental), por exemplo, é uma resposta conservadora às diferenças e seu avanço contraditório na globalização. O Fundamentalismo para Hall representa a reação aos avanços da hibridização da diferença e seus avanços contraditórios, de maneira unitária, homogeneizante e essencialista.

O livro se encerra com uma discussão sobre a diáspora e a estrutura rizomática e fractal que representa o Atlântico Negro. Para Hall a agência criativa negra no novo mundo se deu a 
partir do desenho de uma ideia alternativa de nação política, lida na chave do transnacionalismo negro. Para ele, o termo diáspora está em contraposição ao termo nação e propõe um modelo novo e inovador de abertura da política cultural. Como essa proposição está em aberto, é importante dizer que a noção de diáspora também está sob rasura.

Diáspora para Hall é a metáfora para uma produção discursiva de um novo interstício espacial (terceiro espaço, entre-lugar/tempo) que advém de um longo processo de globalização, cujos elementos chave são os movimentos físicos e culturais de desterritorialização e migração. Esses elementos são chaves para a compreensão de nosso momento atual e os sintomas das consequências de uma conexão global, assim como de sua disjunção. O desafio é compreender como a diáspora pode ser vista por suas similaridades e diferenças e como elas se repetem simultaneamente e estão deslocadas uma da outra.

Hall é um autor que pensa a diáspora em direção ao futuro, não seria correto dizer que sua proposição a respeito do termo sugere um retorno às raízes, ou às tradições culturais. A diáspora não é uma estrutura unitária, se trata da rearticulação de experiências e de pensar a diáspora como um significante de tradução das diferenças, ou seja, pensar em termos de rotas que nos levem a considerar não quem nós somos ou de onde viemos, mas sim quem nós podemos nos tornar e para onde podemos ir.

\section{Referências}

BACK, Les; TATE, Maggie. 'For a Sociological Reconstruction: W.E.B. Du Bois, Stuart Hall and Segregated Sociology'. In: Sociological Research Online. 2018.

BORDA, Erik Wellington Barbosa. Prisma de formação caribenha: a produção social de uma consciência oposicional em C. L. R. James e Oliver C. Cox. PPGS - UFSCar, São Carlos, 2018. Disponível em: https://repositorio.ufscar.br/handle/ufscar/9895?show=full

GILROY, Paul. The Black Atlantic: Modernity and Double Consciousness. Cambridge, Mass. :Harvard University Press, 1993. 


\title{
DESENVOLVIMENTO REGIONAL: Reflexões sobre o caso da SUDENE
}

\section{REGIONAL DEVELOPMENT: Reflections on the case of SUDENE}

\author{
Annahid Burnett ${ }^{1}$ \\ Pedro Maranhão ${ }^{2}$
}

Recebido em 28/01/2021; aceito em 23/09/2021

\begin{abstract}
Resumo: Este artigo traz reflexões sobre o desenvolvimento da região Nordeste à luz do pensamento cepalino, da Teoria da Dependência, do pensamento sobre o imperialismo e a globalização, como também do pensamento social brasileiro, no intuito de fazer uma leitura sobre o processo de implantação do modo de produção capitalista no Nordeste e como se pensar modelos de desenvolvimento regional, como é o caso da Superintendência de Desenvolvimento do Nordeste. Usamos como metodologia a revisão bibliográfica da literatura pertinente e análise documental. Concluímos que o modelo de desenvolvimento absorvido pela Sudene não incorporou mudanças estruturais, resultando no aumento da concentração fundiária e das desigualdades sociais.
\end{abstract}

Palavras-chave: Desenvolvimento do Nordeste; Cepal; Teoria da Dependência; SUDENE

\begin{abstract}
This article brings reflections on the development of the Northeast region in the light of CEPAL thinking, the Theory of Dependency, thinking about imperialism and globalization, as well as Brazilian social thinking, in order to make a reading about the process of implanting the mode of capitalist production in the Northeast and how to think about regional development models, such as the case of the Northeast Development Superintendence. We use as methodology the bibliographic review of the relevant literature and documentary analysis. We conclude that the development model absorbed by Sudene did not incorporate structural changes, resulting in increased land concentration and social inequalities.
\end{abstract}

Keywords: Northeast Development; Cepal; Dependency Theory; SUDENE

\section{Introdução}

O presente artigo propõe uma reflexão sobre o desenvolvimento da região Nordeste, focalizando o caso da Superintendência de Desenvolvimento do Nordeste (SUDENE), utilizando a teoria da dependência e uma análise histórico-estruturalista de cunho cepalino. A primeira foi desenvolvida por um grupo de estudiosos entre meados dos anos 60 e 70 que estavam no Chile,

\footnotetext{
1 Pesquisadora e Professora do Programa de Pós-Graduação em Desenvolvimento Regional da Universidade Estadual da Paraíba - UEPB/PNPD/PPGDR. Doutorado em Ciências Sociais; Mestrado em Sociologia; Licenciatura em Sociologia. Autora do Livro ESTUDO DE CASOS EM ECONOMIA SOCIAL E SOLIDÁRIA (Org.), EDUFPE, 2020. Autora do Livro VOZES FEMININAS (Org.), EDUFPE, 2019. Autora do Livro A SAGA DA ALGAROBA, Ed. NEA, 2018. Autora do Livro VOZES DA SULANCA, Ed. NEA, 2016. Tradutora do Livro SOCIOLOGIA AMBIENTAL do Prof ${ }^{\circ}$ John Hannigan da Universidade de Toronto, Ed. VOZES, 2009. aburnett8@gmail.com

${ }^{2}$ Graduado em Ciências Políticas (UFPE); Mestre em Desenvolvimento Regional (UEPB).

pedromarahao90@gmail.com
} 
destacando os brasileiros que estavam exilados no país andino devido à perseguição política da ditadura brasileira. A segunda foi desenvolvida na Comissão Econômica para América Latina

(CEPAL) também no Chile durante a década de 50, tendo como exponentes o economista argentino Raul Prebisch e o economista brasileiro Celso Furtado, tendo este último ampliado o escopo histórico da teoria sendo configurado o estruturalismo-histórico. Utilizaremos as duas por terem muitos pontos em comum, por explicarem político e socioeconomicamente o lugar do Nordeste Brasileiro na conjuntura nacional e global além de que uma foi usada como instrumento teórico-político principal para a criação da Sudene, já a outra será usada para fazer críticas ao modelo proposto por Celso Furtado e procurar novas inferências sobre o Nordeste brasileiro, a Sudene e seus legados. Para complementar nossa reflexão lançamos mão de autores sobre a globalização e visitaremos o pensamento social brasileiro.

O desenvolvimento do artigo se estrutura em três partes: a primeira discutirá o pensamento cepalino e o método histórico-estruturalista desenvolvido pelos estudiosos na Comissão, assim traremos aportes do economista argentino Raul Prebisch e do economista brasileiro Celso Furtado. A segunda trará pontos da teoria da dependência que serão utilizados no decorrer do artigo, para tanto utilizaremos os autores Gunder Frank, Rosa Luxemburgo, David Harvey, Cardoso e Faletto, Lipietz e Florestan Fernandes. No terceiro trataremos do caso do Nordeste, inserindo tanto no ponto de vista global como nacional, sua categorização no sistema produtivo global, seus problemas socioeconômicos e políticos derivados de sua posição e a criação de um órgão de planejamento para a região, a Sudene. Para tanto utilizaremos os autores Guimarães Neto, Luciléia Colombo, Tânia Bacelar, Manuel Castells, François Chesnais e documentos como o Relatório do GTDN, como também o pensamento social clássico brasileiro de Sérgio Buarque de Holanda, Caio Prado Jr., Florestan Fernandes e Darcy Ribeiro.

\section{O pensamento cepalino}

De acordo com Adelia Miglievich-Ribeiro

Em 1948, havia nascido a Cepal (Comissão Econômica para a América Latina), que aliou o chileno Raul Prebich e o brasileiro Celso Furtado; em 1958, foi fundada a Flacso (Faculdade Latinoamericana de Ciências Sociais), sob a primeira direção de José Medina Echavarria. No Rio de Janeiro foi criado, em 1957, ligado a Unesco, o CLAPCS (Centro 
Latino-Americano de Pesquisas Sociais). Nos inícios dos 1960, a Teoria Desenvolvimentista que inspirara o pioneirismo da Cepal começava a perder potência explicativa diante da persistência da dependência econômica e política latino-americana do capital internacional. Emergiu, assim, a Teoria da Dependência, ou melhor, as teorias da dependência, mediante a crítica ao desenvolvimentismo como até então concebido. Contestando o subdesenvolvimento e o desenvolvimento como etapas de um processo evolutivo, propugnando-os como realidades coetâneas e contrapostas, enfim, se visualizava o subdesenvolvimento como produto mesmo do desenvolvimento capitalista mundial. Diferentes formas de enfrentamento da dependência seriam imaginadas entre os próprios dependentistas, de um lado, Fernando Henrique Cardoso e Enzo Falleto; de outro, Ruy Mauro Marini, Theotonio dos Santos e Vânia Bambirra (MIGLIEVICH-RIBEIRO, 2018 p.30).

O pensamento da CEPAL é dinâmico, seguindo as transformações da realidade econômica, social e política, regional e mundial. Neste artigo apresentaremos as principais ideias dos maiores exponentes do pensamento: Raul Prebisch e Celso Furtado. Desde o final dos anos1940 no escritório da Comissão em Santiago do Chile se desenvolve um método analítico próprio e com ênfase nas estruturas políticas que se mantem insigne hodiernamente:

O estruturalismo é um sistema analítico que tem por base a caracterização das economias periféricas por contraste às centrais: baixa diversidade produtiva (reduzida integração horizontal e vertical, insuficiência de infraestrutura, etc.) e especialização em bens primários; forte heterogeneidade tecnológica e oferta ilimitada de mão-de-obra com renda próxima à subsistência; e, por último, mas não menos importante, estrutura institucional pouco favorável ao progresso técnico e à acumulação de capital. A partir desse contraste, o estruturalismo inclui a análise das relações "centro-periferia", isto é, a análise da forma específica de inserção internacional das economias da América Latina. (BIELSCHOWSKY, 2000, p. 36).

O documento "O Desenvolvimento Econômico da América Latina e Seus Principais Problemas" do economista argentino Raul Prebisch (1949) é basilar: a leitura de que as economias latino-americanas teriam desenvolvido estruturas pouco diversificadas e pouco integradas com um setor primário-exportador dinâmico, mas incapaz de difundir progresso técnico para o resto da economia, de empregar produtivamente o conjunto da mão-de-obra e de permitir o crescimento sustentado dos salários reais foi pioneira. 
Ao contrário do que pregava a doutrina do livre-comércio, esses efeitos negativos se reproduziriam ao longo do tempo na ausência de uma indústria dinâmica, entendida por Prebisch como a principal responsável pela absorção de mão-de-obra e pela geração e difusão do progresso técnico:

O ritmo de incorporação do progresso técnico e o aumento de produtividade seriam significativamente maiores nas economias industriais (centro) do que nas economias especializadas em produtos primários (periferia), o que levaria por si só a uma diferenciação secular da renda favorável às primeiras. Além disso, os preços de exportação dos produtos primários tenderiam a apresentar uma evolução desfavorável frente à dos bens manufaturados produzidos pelos países industrializados. Como resultado, haveria uma tendência à deterioração dos termos de troca que afetaria negativamente os países latino-americanos através da transferência dos ganhos de produtividade no setor primário-exportador para os países industrializados (COLISTETE, 2001, p. 22).

Esta é a principal contribuição de Prebisch para o pensamento da Cepal: a ideia de Deterioração dos Termos de Troca ou Teoria das Trocas Desiguais e seus efeitos econômicos, políticos e sociais nas estruturas. A inserção da atividade industrial como prioridade nas agendas estatais deveria ser urgente para o desenvolvimento dos países latinos. Não deveríamos seguir modelos baseados nas experiências dos países centrais, não é do interesse deles mudanças no status quo. Segundo o argentino devemos criar nossos próprios modelos de crescimento pela experiência direta da vida econômica latino-americana.

Contudo, para Prebisch, a industrialização e a produção primária não são incompatíveis. Precisamos exportar produtos primários para poder importar bens de capital e assim tornar nossas atividades mais tecnologicamente produtivas. Extrair, de um comércio exterior cada vez maior, os elementos propulsores do desenvolvimento econômico. A América Latina necessita de inversões estrangeiras para assimilação técnica necessária ao seu desenvolvimento. Ao mesmo tempo - para evitar problemas na balança de pagamentos - deveríamos ter cuidado com a volatilidade dos preços das commodities e dos serviços financeiros no mercado internacional, pois quem tem o poder de emissão da moeda de comércio internacional, a senhoriagem do Dólar, pode ter interesses divergentes.

Um assunto importante e revisitado por Celso Furtado (2013) trazido no documento é a questão de evitar o consumo conspícuo para a formação do capital necessário para o progresso 
técnico, nós não precisaríamos comprimir o consumo da grande massa, pois já é demasiadamente baixa, deveríamos desviar uma parte importante do aumento da produtividade para a formação de capitais, evitando um consumo prematuro: Trata-se, em última instância, da manifestação do conflito latente entre o propósito de assimilar, precipitadamente, modos de existência que os países de técnicas mais avançadas lograram progressivamente, graças ao aumento de sua produtividade, e as exigências de uma capitalização, sem o qual não nos será possível conseguir aumento semelhante.

No outro lado, Celso Furtado trazia uma bagagem diferente, uma formação jurídica, administrativa pública, econômica e histórica com apoio dos teóricos da Escola de Frankfurt como Mannheim. Utilizando esse aporte, ele estruturou o método histórico-estruturalista que foi largamente utilizado como lente para entender a realidade a partir de então, sendo o livro História Econômica do Brasil vetor inicial da nova metodologia teórica. Para ele, o subdesenvolvimento dos países latino americanos não era fruto apenas das trocas desiguais no comércio, era causado pela condição colonial destes países. O caráter telúrico dos seus estudos fez surgir a questão regional como importante setor do pensamento cepalino.

O método histórico-estrutural analisa a forma como as instituições e a estrutura produtiva herdadas condicionam a dinâmica econômica dos países em desenvolvimento e geram comportamentos que são diferentes do comportamento das nações mais desenvolvidas. Neste método não há estágios de desenvolvimento uniformes. O desenvolvimento tardio de nossos países tem uma dinâmica diferente das nações que experimentaram um desenvolvimento mais precoce. Ao estudar, não apenas a relação entre os países, mas também as dinâmicas internas, Furtado observou as grandes disparidades regionais - modos de produção não capitalistas, estruturas institucionais frágeis, falta de instrução, pouca inovação nas periferias contra estruturas modernas e voltadas para o capitalismo industrial nos centros. Para representar essa desigualdade ele utilizou a expressão heterogeneidade estrutural:

O esquema analítico de Prebisch e Furtado é uma análise histórico-estrutural das persistentes heterogeneidades produtivas e insuficiência na diversificação da estrutura produtiva, e é uma análise das consequências dessas duas características no crescimento, emprego e na distribuição de renda, que devem ser tomadas como referências centrais para formular e instrumentar agendas de reforma e de desenvolvimento. (BIELSCHOWSKY, 2010 p.186) 


\section{A Teoria da Dependência}

A teoria da dependência foi desenvolvida no Chile durante o final dos anos 1960 e começo dos 1970, com o aporte de intelectuais brasileiros que estavam exilados. Ela utiliza conceitos do estruturalismo-histórico cepalino, de Rosa Luxemburgo e do marxismo para fazer uma leitura crítica dos processos de reprodução do subdesenvolvimento na periferia do capitalismo mundial. Segundo Frank (1976), a maioria das categorias técnicas e guias para política e desenvolvimento provém da história das nações avançadas capitalistas europeias e norte-americanas - a periferia não deve esperar que historiadores e intelectuais dos países desenvolvidos criem teorias sobre o subdesenvolvimento periférico. É necessário um pensamento endógeno sobre o desenvolvimento, baseado no passado econômico e história política e social. Para tanto, devemos pensar como funciona o modo de produção capitalista.

Segundo Rosa Luxemburgo (1976), a lei fundamental da produção capitalista não é apenas a busca do lucro, mas sim de lucros sempre crescentes, distinguindo-se de todos os outros modos de produção baseados na exploração. E para atingir esse lucro, mais uma vez ao contrário de outros tipos históricos de exploração, não utiliza os frutos da exploração nem exclusiva nem basicamente para consumo pessoal, mas sim para retroalimentar cada vez mais a própria exploração: a maior fração dos lucros é convertida em capital e utilizada para expandir a produção. Assim, o capital amontoa-se ou, como diz Marx (1959), acumula-se.

Como condições prévias para essa acumulação é necessário que, após reformas políticas ocorridas nas sociedades, como por exemplo a Grande Transformação ocorrida na sociedade inglesa no século XVIII, haja a criação de um exército industrial a ser explorado (POLANYI, 2012). O trabalhador fornece para o patrão o suficiente para o pagamento do seu salário e mais outra parte que é denominada por Marx de mais-valia. Ela não só deve permitir à classe capitalista ter uma existência digna de sua posição social, mas conter também uma fração destinada à acumulação de acordo com Rosa Luxemburgo. Como os trabalhadores recebem salários de subsistência, ou seja, não podem aumentar seus padrões de consumo, pois não é do interesse dos capitalistas nessa fase do capitalismo imperialista, nem poderiam gastar entre si a totalidade da mais-valia: assim não haveria acumulação - analogamente ao sistema escravista ou feudalismo -, segundo Rosa seria um suicídio econômico considerando o capitalismo total. É 
necessário ao capitalista buscar novos mercados consumidores e formas de exploração além do sistema em que vivem. Então, segundo Rosa Luxemburgo, o capitalismo tem de expandir, praticar o subconsumo - relações entre modos de produção capitalistas com sistemas não capitalistas, um processo de acumulação primitiva que se torna exploração e apropriação da propriedade alheia.

Essa relação entre os modos capitalistas e não capitalistas, segundo David Harvey (2003), se dá através de uma série de estratégias imperialistas: 1) política colonial; 2) sistema internacional de empréstimos; 4) guerras; 5) dependência; 6) Força/fraude; 7) pilhagem, entre outros. Com o subconsumo ocorre a sobreacumulação nos países industrializados: esse acúmulo de riquezas precisa de territórios abertos para investimentos e acumulação de capital econômico e político, acesso a insumos baratos para baixos custos e altos lucros. O capitalismo precisa dispor perpetuamente de algo "fora de si mesmo" para se estabilizar. Desse modo é implantada a mercadificação dos insumos e das relações, privatização da terra, expulsão de populações camponesas, conversão das formas de direito de propriedade, supressão de formas autóctones de produção e consumo, processos coloniais, monetização das trocas, taxações, comércio de escravos, usura e sistema de créditos. O Estado com seu monopólio da violência muitas vezes usa dessa prática para objetivos desenvolvimentistas.

Genocídio de culturas, proletarização, direitos de propriedade intelectual, biopirataria, poluição e desmatamento. Esse processo se intensificou a partir da grande transformação trazida pela revolução industrial (POLANYI, 2012). Assim foram criados exércitos industriais de reserva pela tecnologia ou através de formações não capitalistas, os campesinatos, para aumentar os lucros via espoliação da terra comum para criar um proletariado sem-terra como já foi explicado anteriormente.

A partir do estudo das relações econômicas e outras entre as metrópoles e suas colônias no movimento de expansão mundial dos sistemas mercantilistas e capitalistas, Gunder Frank (1976) percebeu: 1) que os países desenvolvidos de hoje nunca estiveram subdesenvolvidos ainda que talvez pudessem ser menos desenvolvidos; 2) O subdesenvolvimento contemporâneo de um país é o produto e reflexo de suas próprias características ou estruturas econômicas, políticas, sociais e culturais e 3) que esse subdesenvolvimento é o produto histórico das relações entre os países satélites subdesenvolvidos com suas metrópoles desenvolvidas - "Lo que es más, 
estas relaciones son parte esencial de la estrutura y el desarrollo del sistema capitalista a escala mundial en conjunto." (FRANK, 1976, p. 22). Esse pensamento carrega similaridades com as teses de desenvolvimento e subdesenvolvimento desenvolvidas por Celso Furtado e também as de Cardoso e Faletto (1973) que trazem a unidade dialética entre a dinâmica geral do capitalismo internacional e a dinâmica interna dos países dependentes, provocando uma reorganização da divisão internacional do trabalho.

Gunder Frank, assim como Furtado, observa que os países subdesenvolvidos são marcados por desigualdades, mas para eles a principal se dá na dualidade dos modos de produção: enquanto um lado é moderno, com modo de produção capitalista, aparentando uma cultura importada da metrópole, desenvolvida; o outro lado é considerado atrasado, feudal, subdesenvolvido, com modos de produção predominantemente não capitalistas. Como foi dito anteriormente essa diferença faz parte do conceito de heterogeneidade estrutural usada pelos Cepalinos. Sendo assim, Frank preconiza três tipos de regiões, 1) as metrópoles centrais que são os países desenvolvidos; 2) as metrópoles coloniais e 3) os satélites periféricos. Como exemplo é mostrado o caso de São Paulo, que é uma metrópole colonial - recebe os bens de capitais dos países desenvolvidos como os EUA ou de instituições financeiras geridas por eles como FMI e Banco Mundial para desenvolver plantas industriais, são Agentes Heteronômicos segundo Florestan Fernandes (1981). A partir desde fato mantêm outras regiões do país como satélites, segundo Gunder Frank, descapitalizando e consolidando seus subdesenvolvimentos: mecanismo debatido por Celso Furtado no GTDN exemplificado nas políticas cambiais brasileiras dos anos 1950.

Cardoso e Faletto ratificam a posição de Gunder Frank ao situar essa análise da reprodução do capitalismo global aos processos históricos de articulação capitalista das classes sociais periféricas e as economias centrais através de cruzamentos sociais e políticos do processo de expansão do sistema capitalista internacional. Os três, junto a Celso Furtado, pelo menos até os anos 1970, fazem duras críticas ao modelo de consumo e estereótipos cujos satélites importam das suas respectivas metrópoles: que não correspondem a suas realidades econômicas nem às suas necessidades de liberdade política. De acordo com Gunder Frank (1976), para se mudar a realidade deve-se primeiro compreendê-la. 
Uma outra hipótese importante na teoria de Gunder Frank é a de que os satélites têm o seu maior desenvolvimento industrial capitalista clássico quando as relações com a metrópole diminuem. Assim ele cita diversos eventos em que ocorreu um isolamento das antigas colônias e nesses intervalos ocorreu um desenvolvimento desses países como nos períodos de crises na Europa: Guerras Napoleônicas, Primeira Guerra Mundial, Depressão financeira dos anos 1930, Segunda Guerra Mundial etc. A primeira fez brotar movimentos de independência na América Latina e as outras foram trazendo liberdades e aumento de demandas. Nesses períodos abriram-se janelas de oportunidades para os satélites desenvolverem atividades que antes eram monopólio das metrópoles.

No caso brasileiro, segundo Celso Furtado no seu livro História Econômica do Brasil, como também segundo Cardoso e Faletto, a partir do final do século XIX, capitalistas brasileiros realizaram inversões dos lucros do café em plantas industriais. No começo eram atividades manufatureiras ligadas ao café e autônomas, contudo a partir do desenvolvimento dessas indústrias houve um crescimento da demanda interna e externa com essas crises na Europa citadas anteriormente, com a Política de Substituições de Importações iniciada no Governo Vargas - a compra do café represado em troca de capital para o desenvolvimento industrial foi um momento de ruptura no desenvolvimento econômico Brasileiro. A partir de então, a questão industrial entrou definitivamente na agenda do Estado, que mais tarde foi trazida à luz juntamente com a questão regional por Celso Furtado no Relatório do GTDN.

\section{O caso da SUDENE}

A região Nordeste do Brasil, segundo Guimarães Neto e Furtado, teve características ímpares de estrutura e desenvolvimento em comparação com outras regiões do país. Segundo o primeiro, podemos periodizá-las em três momentos representativos: 1) Consolidação de uma estrutura econômica e social chamada de Complexo Econômico Regional do Nordeste, constituído de vários segmentos exportadores agrícolas que se associavam a algumas atividades voltadas para o mercado interno como a pecuária; 2) Articulação ao mercado nacional, no movimento de constituição e consolidação de um mercado interno brasileiro; 3) Integração produtiva da região Nordeste através de transferência de capital produtivo público e privado para investimentos enfatizando o industrial. 
Nesse último momento, de acordo com Guimarães Neto - "trata-se, agora, de ter, no interior de sua economia regional, frações de capitais dos grandes grupos econômicos que já marcavam presença nas regiões mais industrializadas do país" (GUIMARÃES NETO, 1997 p.3). Ou seja, essas mudanças instituem, ou pelo menos oficializam, o modelo fordista de produção na região, com o estímulo ao consumo de massa regulado por políticas keynesianas, criando a sociedade salarial, um novo estilo de vida (HARVEY, 1989). Contudo, a região não possuía uma classe operária experiente, com pessoal de apoio para aplicar os modos de produção fordista, com isso a produção não podia atingir o potencial previsto e junto com outros pontos, como a distância tecnológica, forte êxodo rural e insípidos aumentos salariais dos operários, podemos caracterizá-la como Fordismo Periférico (LIPIETZ, 1989).

Porém, voltando ao texto de Guimarães Neto, essa passagem do Nordeste ${ }^{3}$ do segundo para o terceiro período se deu através da ação do Governo Federal com a criação da Sudene, Superintendência de Desenvolvimento do Nordeste:

"O documento Uma Política de Desenvolvimento Econômico para o Nordeste também conhecido como Relatório do GTDN elaborado pelo grupo liderado por Celso Furtado em 1959 foi o primeiro plano de desenvolvimento regional e também a primeira abordagem estrutural e integrada de planejamento do Brasil. Até então, o mais importante instrumento de planejamento tinha sido o Plano de Metas de Juscelino Kubitschek, além de alguns planos setoriais que constituíam, praticamente, coleção de projetos. A política do GTDN contempla uma intervenção combinada e diferenciada nas estruturas econômicas do Nordeste com uma visão sistêmica que busca uma síntese das relações econômicas e sociais e suas características específicas”. (BUARQUE, 2017, p. 15)

Utilizando o pensamento cepalino e o método histórico-estruturalista o plano faz um panorama econômico da região, divulgando suas vantagens comparativas e manifestando seus subdesenvolvimentos. A estratégia do GTDN se estruturou em quatro vetores de transformação articulados e integrados que sintetizam a necessidade de dinamização da economia, com a redução da vulnerabilidade às secas, geração de emprego e renda: 1) Transformação da economia

\footnotetext{
${ }^{3}$ Para evitar dúvidas sobre a área de atuação da Superintendência de Desenvolvimento do Nordeste, ela não se limita ao Nordeste, contudo, as outras regiões, como o Norte de Minas Gerais e Espírito Santo foram incluídas por estarem contíguas e pelos mesmos motivos: baixo desenvolvimento econômico. A história do Nordeste se confunde com esses outros espaços sendo eles também artefatos políticos da autarquia.
} 
agrária da faixa úmida da Zona da Mata; 2) Transformação da economia das zonas semiáridas com elevação da produtividade e tornando mais resistente ao impacto das secas; 3) Deslocamento da fronteira agrícola do Nordeste com incorporação das terras úmidas do hinterland maranhense para receber os excedentes populacionais criados pela reorganização da economia do semiárido e 4) Industrialização da economia, combinando a reorganização e aumento da produtividade das indústrias tradicionais, e modificação da estrutura industrial com a implantação de uma indústria de base.

Em uma janela de oportunidade aberta (KINGDON, 1995) para a implementação de políticas públicas devido à conjuntura política nacional: forte seca de 1958 no Nordeste, crise no Governo Federal, Ligas Camponesas, Revolução Cubana, Apoio eclesiástico entre outros fatos uma forte mobilização nacional dirigida por Celso, Juscelino, burguesia nacional e alguns jornais como o Correio da Manhã galvanizam o projeto do GTDN em detrimento ao antigo modelo de solução hidráulica para a região representado pelo $\mathrm{DNOCS}^{4}$ (COLOMBO, 2015). A partir de então, é criado o Conselho de Desenvolvimento do Nordeste (Codeno) através de um Decreto de JK, Furtado empenha-se em promover encontros pelo Nordeste para aglutinar interesses e buscar sinergias com as burguesias, intelectualidades e atores locais interessados na construção da superintendência.

Após meses de trabalho em dezembro de 1959 a Sudene é instituída tendo como seu principal trunfo político a criação Conselho Deliberativo da autarquia, espaço democrático de concertação regional. Segundo Lucileia Colombo (2015) - O Conselho Deliberativo representou uma esfera de resolução dos problemas de ação coletiva por meio de seu regimento interno, que tinha o poder de coordenar, coagir e mobilizar os governadores para agir juntamente. Como diretrizes principais da autarquia foi elaborado nesse Conselho Deliberativo o Plano Diretor da Sudene cuja base era o GTDN acompanhado das ideias debatidas no Conselho.

\footnotetext{
4 Dentre os órgãos regionais, o Departamento Nacional de Obras Contra as Secas - DNOCS, se constituiu na mais antiga instituição Federal com atuação no Nordeste. Criado sob o nome de Inspetorias de Obras Contra as Secas - IOCS, através do Decreto 7.619 de 21 de outubro de 1909 , editado pelo então Presidente Nilo Peçanha, foi o primeiro órgão a estudar a problemática do semiárido. O DNOCS recebeu ainda em 1909 (Decreto 13.687), o nome de Inspetoria Federal de Obras Contra as Secas - IFOCS, antes de assumir sua denominação atual, que lhe foi conferida em 1945 (Decreto-Lei 8.846, de 28/12//1945) vindo a ser transformado em autarquia federal, através da Lei n $\mathrm{n}^{\circ}$ 4229, de 01/06/1963. Sendo de 1909 até por volta 1959, praticamente, a única agência governamental federal executora de obras de engenharia na região, fez de tudo. Construiu açudes, estradas, pontes, portos ferrovias, hospitais e campos de pouso, implantou redes de energia elétrica e telegráficas, usinas hidrelétricas e foi, até a criação da SUDENE, o responsável único pelo socorro às populações flageladas pelas cíclicas secas que assolam a região (Fonte: www.dnocs.gov.br / acesso em julho 2019).
} 
Porém, o GTDN não contemplou, ou simplesmente, negligenciou o cerne do problema regional nordestino: A Questão Agrária. De acordo com Sérgio Buarque de Holanda em Raízes do Brasil

Toda estrutura de nossa sociedade colonial teve sua base fora dos meios urbanos. É preciso considerar esse fato para se compreenderem exatamente as condições que, por via direta e ou indireta, nos governaram até muito depois de proclamada nossa independência política e cujos reflexos não se apagaram ainda hoje. Se, não foi a rigor uma civilização agrícola o que os portugueses instauraram no Brasil, foi, sem dúvida, uma civilização de raízes rurais (BUARQUE DE HOLLANDA, 1995 p. 73).

Caio Prado Jr. na sua obra Formação do Brasil Contemporâneo corrobora tal pensamento

O caráter fundamental da nossa economia está na produção extensiva para mercados do exterior, e correlata falta de um largo mercado interno solidamente alicerçado e organizado. Donde a subordinação da economia brasileira a outras estranhas a ela; subordinação, aliás, que se verifica também em outros setores. Numa palavra, não completamos ainda hoje a nossa evolução da economia colonial para a nacional. No terreno social a mesma coisa. Salvo em alguns setores do país, ainda conservam nossas relações sociais, em particular as de classe, um acentuado cunho colonial (PRADO JR., 2011, p. 10).

Foi a grande exploração agromercantil de base territorial necessariamente extensa, que figurou no centro das atividades rurais na generalidade de suas regiões e zonas geoeconômicas no Brasil. E foi em função desse "setor principal" que se constituiu, se manteve e evoluiu o outro "setor secundário" das atividades rurais, é o que Caio Prado Jr. (2000) denomina de "bimodelismo".

Neste sentido, Florestan Fernandes na sua obra Sociedades de Classes e Subdesenvolvimento argumenta que

A formação de um Estado nacional independente desenrolou-se sem que se processassem alterações anteriores ou concomitantes na organização da economia e da sociedade. Portanto, ela se deu sem que o regime de castas e estamentos sofresse qualquer crise, pois ele constituiu a base econômica e social da transformação dos "senhores rurais" numa aristocracia agrária. Sob esse aspecto, a inclusão da economia brasileira no mercado mundial representou um simples episódio do ciclo de modificações dos laços coloniais, no quadro histórico criado pela elevação da Inglaterra à condição de grande potência colonial. Os laços coloniais apenas mudaram de caráter e sofreram uma transferência: deixaram de ser jurídico-políticos, para se secularizarem e se tornarem 
puramente econômicos; passaram da antiga Metrópole lusitana para o principal centro de poder do imperialismo econômico nascente (FERNANDES, 1981, p.22).

Nesta perspectiva, ao analisarmos o caso específico do Nordeste, tomamos a explicação de Darcy Ribeiro na sua obra basilar O povo brasileiro - A formação e o sentido do Brasil

Para além da faixa nordestina das terras frescas e férteis do massapé, com rica cobertura florestal, onde se implantaram os engenhos de açúcar, desdobram-se as terras de uma outra área ecológica (1995, p. 339). No agreste, depois nas caatingas e, por fim, nos cerrados, desenvolveu-se uma economia pastoril associada originalmente à produção açucareira como fornecedora de carne, de couros e de bois de serviço. Foi sempre uma economia pobre e dependente (1995, p.340). A expansão desse pastoreio se fazia pela multiplicação e dispersão dos currais, dependendo da posse do rebanho e do domínio das terras de criação. O gado devia ser comprado, mas as terras, pertencendo nominalmente à Coroa, eram concedidas gratuitamente em sesmarias aos que se fizessem merecedores do favor real. Nos primeiros tempos, os próprios senhores de engenho da costa se faziam sesmeiros da orla do sertão, criando ali o gado que se consumiam. Depois, esta se tornou uma atividade especializada de criadores, que formaram os maiores detentores de latifúndios no Brasil. O mais célebre deles foi um baiano tão rico que deixou em testemunho, a favor dos jesuítas, recursos para rezarem missas por uma alma até o fim do mundo (RIBEIRO, 1995, p.341, grifos dos autores).

Após décadas de atuação da Sudene estudiosos trazem pontos positivos da atuação da autarquia como a criação de infraestrutura para a região, da sua busca por formar mão de obra capacitada através da instituição de cursos e universidades, do aumento industrial na região, dos auxílios técnicos em diversos setores e também de um ponto controvertido - o financiamento de projetos. (BUARQUE, 2017; COLOMBO, 2015). Também houve uma gigante diversificação das atividades econômicas: o complexo petroquímico de Camaçari e a plantação de feijão e soja no Oeste baiano (BA), a agroindústria de Petrolina, SUAPE e o complexo industrial da Região Metropolitana de Recife (PE), as indústrias extrativas do Maranhão dentre outras (ARAÚJO, 2000). Segundo esses estudiosos, apesar da grande mudança nas últimas décadas a região continua relativamente atrasada, com grande defasagem econômica e social comparada com o restante do país. Houveram mudanças, mas nada significativo, a porcentagem do PIB do Nordeste em relação ao Brasil pouco mudou, de 11\% para 13\% entre 1959 e 2013 (BUARQUE, 2017). 
Segundo Cardoso, Fernandes e Harvey é necessária uma ação coletiva dos trabalhadores para que, através do fortalecimento das lutas sindicais, o aumento da produtividade mediante novas tecnologias e técnicas sejam distribuídas menos desigualmente entre as classes da sociedade. Algo que Furtado não trazia nos seus pensamentos clássicos. Olhando a situação do Nordeste cuja atividade sindical, como foi dito antes, não tinha a tradição do Sudeste, pode-se inferir que os lucros nem de perto foram bem distribuídos, situação diferente dos pactos sociais realizados entre as forças patronais e sindicais nos países desenvolvidos fordistas (HARVEY, 1989).

Com o passar dos anos o Conselho Deliberativo da Sudene foi se esvaziando e os governadores passaram a agir individualmente em busca de seus interesses, enfraquecendo a política regional e criando embates políticos e econômicos como a Guerra Fiscal. Outras instituições como o BNB e o BNDES se fortaleceram e ocuparam o espaço antes predominado pela autarquia. Os interesses e os recursos de financiamento e isenções fiscais foram diminuindo, além de casos de corrupção começarem a virem à tona a partir dos anos 90 (COLOMBO, 2015). Pode-se relacioná-los com o patrimonialismo e clientelismo presente na cultura brasileira cujos favores e ausência de distinção entre o público e o privado permeiam as instituições públicas.

Vemos no século XXI o Brasil como um todo, mas especialmente o Nordeste, sem grandes perspectivas de um lugar ao sol na globalização, financeirização econômica e na nova economia informacional de sociedade em redes (CASTELLS, 2011; CHESNAIS, 1996). A Sudene foi extinta em 2001, e, com certo esforço, reabriram-na em 2007, contudo não lhe deram instrumentos monetários, recursos humanos e infraestrutura para exercer seu papel de promotor do desenvolvimento regional. Nessa nova época informatizada, com as distâncias progressivamente encurtadas, as culturas sendo sobrepostas e ao mesmo tempo as diferenças com mais contrastes - que inovação no modelo de desenvolvimento regional podemos pensar?

\section{Conclusões}

Duas teorias, uma que emergiu da outra, trazem leituras pouco diferentes acerca da reprodução do sistema de produção capitalista sobre o desenvolvimento dos países. Encontraram terreno fértil, época de grandes transformações nos modelos de produção, de Guerra Fria, de inovações tecnológicas, de crescimento de universidades e novas instituições como foi o caso da 
Cepal sob liderança de Prebisch cujas ações tiveram amplo impacto na América Latina. No Brasil, Celso Furtado encontrou um ambiente amplamente receptivo, tanto no setor público como privado, de sua metodologia no intuito de concretizar seu plano de planejamento regional.

No outro lado a Teoria da Dependência trouxe com mais ênfase o caráter do desenvolvimento e subdesenvolvimento entre os países, trazendo Rosa Luxemburgo e Gunder Frank para pensar as formas de imperialismo das metrópoles centrais até os satélites que caracterizam as relações de subconsumo. Florestan Fernandes traz o conceito de agente heteronômico e como se dão as espoliações tão bem dissertadas por David Harvey para os processos de sobreacumulação. Com as teorias de globalização e da sociedade em redes, novas inferências podem ser discutidas e trazidas para essa dimensão regional, que muitas vezes é considerada retrógrada por pesquisadores ou que não está na agenda principal dos estados, a fim de trazer inovações ao debate.

No caso da Sudene, a observação científica de Florestan Fernandes (1981) sobre as classes sociais é bastante pertinente. Ele constata que as classes dominantes dos senhores rurais que se formaram no Brasil colônia, a partir dos fidalgos portugueses, passaram a compor a aristocracia agrária no Brasil Império subjugado ao britânico, mas sem passar por uma conversão histórica. Por sua vez, no Brasil República, essa aristocracia agrária se converteu em burguesia durante a época da industrialização, na primeira fase de substituição de importações e se reforçou no pós-guerra na segunda fase de substituição de importações, sob a ascensão do império americano, através da implantação das multinacionais fordistas no Brasil. Ou seja, no Nordeste essa classe era representada pelos latifundiários e as práticas patrimonialistas, coronelistas e clientelistas da Sudene, só fizeram aumentar a concentração de terras e renda, sem, no entanto, resolver a questão agrária e a desigualdade social.

\section{Referências}

ARAÚJO, T. Nordeste, Nordestes: que Nordeste? Ensaios sobre o desenvolvimento brasileiro. Heranças e Urgências. Rio de Janeiro: Revan Fase, p.165-196. 2000.

BIELSCHOWSKY, R. Vigência das contribuições de Celso Furtado ao estruturalismo. Revista da CEPAL, número especial em português, p. 183-191. 2010. Disponível em: http://repositorio.cepal.org/bitstream/handle/11362/11397/NEP183191.pdf?sequence=1. Acesso em 5 oct. 2018. 
BIELSCHOWSKY, R.; FORMIGA, M.; SACHS, I. (Coord). Seminário Internacional "Celso Furtado, a Sudene e o Futuro do Nordeste". Recife: Sudene, 357p. 2000.

BUARQUE, S. Celso Furtado, o desvelador da realidade nordestina. Recife: Fundação Joaquim Nabuco, 128 p. 2017.

BUARQUE DE HOLANDA, Sérgio. Raízes do Brasil. São Paulo: Companhia das Letras, 219 p. 1995.

CARDOSO, F. H. Teoria da dependência ou análises concretas de situações de dependência. $2^{\circ}$ Seminário Latino-americano para El Desarrollo, p. 26-45. Santiago: Chile, FLACSO; UNESCO. 1970.

CARDOSO, F. H. As ideias e seu lugar. Petrópolis: Vozes, 244 p. 1995.

CARDOSO, F; FALETTO, E. Dependência e desenvolvimento na América Latina. São Paulo: Zahar, 143 p. 1973.

CASTElls, M. A Sociedade em Rede. São Paulo: Paz e Terra, 263 p. 2011.

CHESNAIS, F. A mundialização do capital. São Paulo: Xamã, 335 p. 1996.

COLISTETE, R. O desenvolvimentismo cepalino: problemas teóricos e influências no Brasil. Estudos Avançados. vol.15 no.41 São Paulo, p 21-34.2001. Disponível em: http://www.scielo.br/scielo.php?script=sci arttext\&pid=S0103-40142001000100004\#not1.

Acesso em 2 oct. 2018.

COLOMBO, L. A Sudene no sistema federativo brasileiro: a ascensão e queda de uma instituição. Recife: Superintendência de Desenvolvimento do Nordeste, 292 p. 2015.

FERNANDES, F. Sociedade de classes e subdesenvolvimento. São Paulo: Zahar, 267 p. 1981

FRANK, G. América Latina: subdesarrollo o revolución. Mexico: Ediciones Era, 357 p. 1976. FURTADO, C. Essencial. São Paulo: Companhia das Letras, 257 p. 2013.

FURTADO, C. Formação Econômica do Brasil. São Paulo: Companhia das Letras, 352 p. 2007.

KINGDON, J. Agendas, alternatives and public policies. 2ed Addison-Wesley Educational Publishers Inc., 254 p. 1995. 
HARVEY, D. A condição pós-moderna: uma pesquisa sobre as origens da mudança cultural. São Paulo: Loyola, 349 p. 1989.

HARVEY, D. O novo imperialismo. São Paulo: Edição Loyola. 201 p. 2003.

LIPIETZ, A. Fordismo, Fordismo periférico e Metropolização. Ensaios FEE, Porto Alegre: 10(2):303-335. 1989.

LUXEMBURGO, R.; BUKHARINE, N. Imperialismo e acumulação de capital. Lisboa: Edições 70, 346 p. 1976.

MARX, Karl. Le Capital - Critique de L'Économie Politique, Livre Premier, Le Dévelopment de La production Capitaliste.Traduction de Joseph Roy et entièrement revisée par l'auteur. Paris: Éditions Sociales, 317 p. 1959.

MICLIEVICH-RIBEIRO, Adelia M. Darcy Ribeiro e Utopia no Exílio LatinoAmericano: "Estruturas de Sentimentos" como Hipótese Metodológica. Revista TOMO. São Cristóvão: Sergipe, Brasil, n. 32, p. 15-40. 2018.

POLANYI, K. A grande transformação. Rio de Janeiro: Elsevier, 349 p. 2012.

PRADO Jr., Caio. A Questão Agrária no Brasil. São Paulo: Brasiliense, 188 p. 2000.

PRADO Jr., Caio. Formação do Brasil Contemporâneo. São Paulo: Companhia das Letras, 446 p. 2011.

PREBISCH, R. O Desenvolvimento Econômico da América Latina e seus Principais Problemas. $1949 . \quad$ Disponível em: http://bibliotecadigital.fgv.br/ojs/index.php/rbe/article/view/2443. Acesso em 02 set. 2018, 65 p. RIBEIRO, Darcy. O povo brasileiro - A formação e o sentido do Brasil. São Paulo: Companhia das Letras, 476 p. 1995 . 


\title{
A produção do legislativo brasileiro acerca da Convenção americana de Direitos Humanos
}

\section{The production of brazilian legislative about the American Convention on Human Rights}

\author{
Marcírio Barcellos Gessinger ${ }^{1}$
}

Recebido em 01/09/2021; aceito em 16/12/2021

\begin{abstract}
Resumo: O artigo busca compreender como o Legislativo brasileiro procura regulamentar a Convenção Americana de Direitos Humanos. As produções legislativas são todas, à exceção de uma, voltadas às indenizações das vítimas e não à prevenção de novas violações de direitos humanos. Dessa forma, o Legislativo brasileiro procura regulamentar a Convenção Americana de Direitos Humanos somente em relação às indenizações impostas ao país.
\end{abstract}

Palavras-chave: Legislativo brasileiro; Convenção Americana de Direitos Humanos; Marxismo.

\begin{abstract}
The paper seeks to understand how the Brazilian Legislative tries to regulate the American Convention on Human Rights. All legislative production, with the exception of a decree, is turned to restitution for the victims and not to prevention of human rights violations. Hence, the Brazilian Legislative tries to regulate the American Convention on Human Rights regarding only restitutions imposed on the country by the Inter-American Court of Human Rights.
\end{abstract}

Keywords: Brazilian legislative; American Convention on Human Rights; marxism.

\section{INTRODUÇÃO}

Entre 2009 e 2020, o Brasil já foi condenado oito vezes pela Corte Interamericana de Direitos Humanos (Corte IDH) ${ }^{2}$. Isso significa que o país violou em, pelo menos, oito ocasiões distintas, a Convenção Americana de Direitos Humanos. Desses oito casos, seis possuem supervisão de cumprimento das condenações e em nenhum deles há cumprimento total do disposto nas sentenças, conforme tabela abaixo:

\footnotetext{
${ }^{1}$ Mestrando em Direito pelo Programa de Pós-Graduação em Direito da Universidade Federal do Rio Grande do Sul - PPGS/UFRGS. E-mail: marciriogessinger@yahoo.com.br. Av. João Pessoa, 80 - Centro Histórico, Porto Alegre RS, 90040-000

${ }^{2}$ Dados retirados do site do Ministério Público Federal:

$<$ http://www.mpf.mp.br/atuacao-tematica/sci/dados-da-atuacao/corte-idh>. Acesso em: 10 fev. 2021.
} 
Composição, Revista de Ciências Sociais da Universidade Federal de Mato Grosso do Sul. ISSN: 1983-3784. v 2, n 25 - p 30-43. Jul-dez 2021. Doi: https://doi.org/10.36066/compcs.v2i25.13949

Tabela 01 - Sentenças da Corte Interamericana de Direitos Humanos em que o Brasil foi condenado e suas respectivas supervisões

\begin{tabular}{|c|c|c|c|}
\hline Caso & Data & Sentença & Supervisão \\
\hline HERZOG E OUTROS & $15 / 03 / 2018$ & $\begin{array}{l}\text { http://www.corteidh.or.cr } \\
\text { /docs/casos/articulos/seri } \\
\text { ec_353_por.pdf }\end{array}$ & Não há \\
\hline $\begin{array}{l}\text { POVO INDÍGENA } \\
\text { XUCURU E SEUS } \\
\text { MEMBROS }\end{array}$ & 05/08/2018 & $\begin{array}{l}\text { http://www.corteidh.or.cr } \\
\text { /docs/casos/articulos/seri } \\
\text { ec_346_por.pdf }\end{array}$ & Não há \\
\hline $\begin{array}{l}\text { FAVELA NOVA } \\
\text { BRASÍLIA }\end{array}$ & $16 / 02 / 2017$ & $\begin{array}{c}\text { http://www.corteidh.or.cr } \\
\text { /docs/casos/articulos/seri } \\
\text { ec_333_por.pdf }\end{array}$ & $\begin{array}{c}\text { http://www.corteidh.or.cr } \\
\text { /docs/asuntos/favela_fv_ } \\
\text { 18.pdf }\end{array}$ \\
\hline $\begin{array}{l}\text { TRABALHADORES } \\
\text { DA FAZENDA } \\
\text { BRASIL VERDE }\end{array}$ & $20 / 10 / 2016$ & $\begin{array}{c}\text { http://www.corteidh.or.cr } \\
\text { /docs/casos/articulos/seri } \\
\text { ec_318_por.pdf }\end{array}$ & Não há \\
\hline $\begin{array}{l}\text { GOMES LUND E } \\
\text { OUTROS }\end{array}$ & $24 / 11 / 2010$ & $\begin{array}{c}\text { http://www.corteidh.or.cr } \\
\text { /docs/casos/articulos/seri } \\
\text { ec_219_por.pdf }\end{array}$ & $\begin{array}{l}\text { http://www.corteidh.or.cr } \\
\text { /docs/supervisiones/gom } \\
\text { es_17_10_14.pdf }\end{array}$ \\
\hline GARIBALDI & 23/09/2009 & $\begin{array}{l}\text { http://www.corteidh.or.cr } \\
\text { /docs/casos/articulos/seri } \\
\text { ec_203_por.pdf }\end{array}$ & $\begin{array}{l}\text { http://www.corteidh.or.cr } \\
\text { /docs/supervisiones/garib } \\
\text { aldi_20_02_12.pdf }\end{array}$ \\
\hline ESCHER E OUTROS & 06/07/2009 & $\begin{array}{l}\text { http://www.corteidh.or.cr } \\
\text { /docs/casos/articulos/seri } \\
\text { ec_200_por.pdf }\end{array}$ & $\begin{array}{l}\text { http://www.corteidh.or.cr } \\
\text { /docs/supervisiones/esch } \\
\text { er_19_06_12.pdf }\end{array}$ \\
\hline XIMENES LOPES & $04 / 07 / 2006$ & $\begin{array}{l}\text { http://www.corteidh.or.cr } \\
\text { /docs/casos/articulos/seri } \\
\text { ec_149_por.pdf }\end{array}$ & $\begin{array}{l}\text { http://www.corteidh.or.cr } \\
\text { /docs/supervisiones/xime } \\
\text { nes_17_05_10.pdf }\end{array}$ \\
\hline
\end{tabular}

Fonte: produzido pelo autor (2021).

A jurisdição da Corte IDH foi reconhecida pelo Brasil em 2002 através do Decreto $\mathrm{n}^{\circ}$ 4.463 (BRASIL, 2002) para fatos posteriores a 10 de dezembro de 1998. O Sistema Interamericano de Direitos Humanos, por sua vez, depende da judicialização dos processos, tanto a análise quanto o cumprimento dos casos (BERNARDI, 2017).

Para que um caso seja julgado pela Corte IDH, é necessário que a Comissão Interamericana de Direitos Humanos (CIDH) admita a petição, que contém as possíveis violações da Convenção, e a remeta para julgamento. Por outro lado, é possível que haja 
tentativa de solução amigável supervisionada pela CIDH sem que o caso seja "remetido" à Corte IDH (BRASIL, 1992). Ou seja, os casos judicializados não são as únicas situações potenciais de violação de direitos humanos que constam no Pacto de São José da Costa Rica, sendo o Caso Maria da Penha um bom exemplo ${ }^{3}$.

Parte do cumprimento do caso acima se deve à promulgação da Lei Maria da Penha (Lei $\left.\mathrm{n}^{\mathrm{o}} 11.340 / 2006\right)$ que, inclusive, tem parecer da CIDH como um ponto importante na sua exposição de motivos (FREIRE, 2004). O cumprimento de condenação de pagar quantia determinada pela Corte IDH, no Brasil, depende de decreto do Presidente da República, como é o caso do Decreto $n^{\circ} 7.307 / 22$ referente à condenação pecuniária relacionada ao Caso Garibaldi (BRASIL, 2010). Por outro lado, o cumprimento de condenação de fazer ou de deixar de fazer não tem um regramento específico na legislação brasileira, ficando à sorte de uma vontade política do Legislativo. Dessa forma, a promulgação da Lei Maria da Penha não é a regra, mas sim, a exceção. Inclusive, o próprio tratado em questão prevê que cada Estado Parte regulamentará os mecanismos para cumprimento das sentenças:

Há o dever do Estado de cumprir integralmente a sentença da Corte, conforme dispõe expressamente o art. 68.1 da seguinte maneira: "Os Estados Partes na Convenção comprometem-se a cumprir a decisão da Corte em todo caso em que forem partes". É tarefa do Estado escolher o meio de execução, que em geral depende do tipo de órgão imputado (por exemplo, se judicial ou não) e de seu status normativo (RAMOS, 2014, p. 314).

Em teoria, não haveria restrição alguma da vítima ou de seus sucessores legais ajuizarem ação buscando o cumprimento da sentença internacional, visto que a Constituição prevê em seu art. $5^{\circ}$, inciso XXXV, que o Judiciário deverá apreciar possível lesão ou ameaça a direito (BRASIL, 1988). A resposta a ser recebida, entretanto, pode variar drasticamente. De um lado, pode-se pensar no julgamento da Ação de Descumprimento de Preceito Fundamental n ${ }^{\circ} 153$, julgada pelo Supremo Tribunal Federal, no qual, ao decidir que o artigo primeiro da Lei da Anistia seria compatível com a Constituição Federal, foi de encontro com o julgamento do caso Gomes Lund ${ }^{4}$ (GALLO, 2018). Em outro extremo, tem-se o posicionamento minoritário ${ }^{5}$ do Tribunal Regional do Trabalho da Quarta Região (TRT4) de afastar os honorários

\footnotetext{
${ }^{3}$ Nesse contexto, o Brasil possui doze casos sob supervisão direta pela CIDH, todos com cumprimento parcial, inclusive o Caso Maria da Penha (ORGANIZAÇÃO DOS ESTADOS AMERICANOS, 2021).

${ }^{4}$ E posteriormente do caso Herzog.

${ }^{5} \mathrm{O}$ voto do desembargador Marcelo José Ferlin D’Ambroso é o vencido no acórdão apresentado.
} 
sucumbenciais, introduzidos pela Reforma Trabalhista em razão de sua inconvencionalidade frente à $\mathrm{CADH}$ :

O Brasil é signatário da Convenção Americana de Direitos Humanos (Pacto de São José da Costa Rica), tratado no qual se comprometeu, perante a comunidade internacional, a observar os direitos humanos ali previstos, nos quais se colhe o acesso à justiça facilitado quando se tratar de garantias fundamentais. (BRASIL, 2019b)

É importante lembrar que o Direito Internacional reconhece o papel primário das cortes nacionais, especialmente em razão da soberania (NOLLKAEMPER, 2011). Dessa maneira, o objeto dessa pesquisa é a (in)existência dessa vontade política do Legislativo. Haveria alguma intenção de regulamentar a execução de sentenças provenientes da Corte IDH? Se houver, qual o conteúdo da regulamentação? Para isso, utilizar-se-á de pesquisa efetuada no site LexML, conforme será abordado no próximo tópico. Então, uma vez apresentados os dados alcançados, lançar-se-á mão do marco teórico da Teoria Marxista do Direito para compreendê-los.

\section{METODOLOGIA E APRESENTAÇÃO DE DADOS}

A ferramenta de pesquisa utilizada foi o site LexML, plataforma que tem por objetivo reunir informações jurídicas e legislativas, como jurisprudência, projetos de lei e decretos, de iniciativa liderada pelo Senado Federal (KRAUSS; LIMA; LIMA, 2016). Foram procurados os termos "Convenção Americana de Direitos Humanos"; "Corte Interamericana de Direitos Humanos"; e "Comissão Interamericana de Direitos Humanos" no período de dezembro de 1992 a março de 2020, ou seja, a partir da ratificação da CADH até o início da pesquisa. Uma vez encontrados os resultados, foram excluídos aqueles referentes à própria Convenção, e separados em dois grupos: legislação e propostas de legislação ${ }^{6}$. Desse jeito, foram analisados todos os resultados encontrados, aplicando-se, portanto, o método de censo.

Primeiramente, no grupo da legislação, não há resultados para o termo "Convenção Americana de Direitos Humanos" além do próprio texto e de seus protocolos. Para o termo “Corte Interamericana de Direitos Humanos", por sua vez, há três decretos: $n^{\circ}$ 7.307/10 (BRASIL, 2010b); $n^{\circ} 7.158$ (BRASIL, 2010a); e no 6.185/07 (BRASIL, 2007b). Esses decretos autorizam a Secretaria Especial dos Direitos Humanos da Presidência da República a dar

\footnotetext{
${ }^{6}$ Da análise, não se levou em conta o partido político de quem propôs a legislação, uma vez que foge ao escopo do artigo, consoante será explicado no marco teórico.
} 
cumprimento à sentença exarada pela Corte Interamericana de Direitos Humanos aos Casos Garibaldi, Escher e Ximenes Lopes, respectivamente, no tocante à obrigação de pagar quantia. Percebe-se que não há inovação jurídica, mas somente a autorização ao pagamento das indenizações às vítimas, sejam elas parentes ou a própria pessoa vitimada.

Ainda, referente à legislação, foram encontrados quatro decretos quando da procura pelo termo "Comissão Interamericana de Direitos Humanos": $n^{\circ}$ 50.067/05 (BRASIL, 2005a); $n^{\circ}$ 51.678/07 (BRASIL, 2007a) no 5.611/05 (BRASIL, 2005b); e $n^{\circ}$ 5.619/05 (BRASIL, 2005c). Aqueles primeiros advém da Assembléia Legislativa do Estado de São Paulo, dispondo sobre a representação do Estado nos assuntos da CIDH e instituindo um grupo de trabalho para estudar o cumprimento das recomendações oriundas do relatório nº66/06 da CIDH; enquanto esses últimos dispõem sobre o cumprimento do relatório relativo ao caso Ovelário Tames e ao Acordo de Composição Amistosa dos casos $n^{o s} .12 .426$ e 12.427, nessa ordem. A legislação existente sobre o assunto, além dos próprios textos da Convenção e de seus protocolos, assim, cuida especificamente da indenização às vítimas, não regulamentando a matéria além do necessário para o cumprimento da obrigação de pagar.

As propostas de legislação, por seu turno, guardam características semelhantes ao conteúdo dos decretos acima analisados. Em relação ao termo "Convenção Americana de Direitos Humanos", o único resultado foi o projeto de decreto legislativo $\mathrm{n}^{\circ} 1.595 / 05$. (BRASIL, 2005d) que pretendia fazer equivaler a CADH a uma Emenda Constitucional. Acabou por ser reputado "evidentemente inconstitucional" e, posteriormente, arquivado (BRASIL, 2005e).

No que se refere às propostas de legislação a partir da procura do termo "Corte Interamericana de Direitos Humanos", encontrou-se o projeto de lei $n^{0} 153 / 2020$, que estabelece diretrizes para execução das indenizações fixadas pela Corte IDH, como, a título exemplificativo, tornando a sentença condenatória em título executivo judicial, podendo, desse jeito, ser executado diretamente em juízo (BRASIL, 2019a). Igualmente, constou da pesquisa o projeto de lei $\mathrm{n}^{\circ}$ 220/16 que, a exemplo do projeto acima citado, versa sobre a execução de indenizações advindas da condenação pela Corte IDH e das decisões da CIDH (BRASIL, 2016). Por fim, deparou-se com o projeto de lei n 420/09 que, também, versa sobre a classificação da sentença condenatória da Corte IDH, no que tange à indenização, como título executivo judicial (BRASIL, 2009). Os dois primeiros projetos referenciados ainda estão em tramitação, não tendo sido votados, ao passo que o último, foi tido por prejudicado e arquivado em 2010. No tocante ao 
termo "Comissão Interamericana de Direitos Humanos", repetem-se os projetos de lei no 153/2020 e no 220/16, não havendo outros resultados.

Em resumo, de dezembro de 1992 a março de 2020, houve a) cinco decretos do Presidente da República dispondo sobre indenização às vítimas de violações do Brasil à Convenção Americana de Direitos Humanos; b) um decreto sobre representação do Estado de São Paulo perante à CIDH; c) um decreto instituindo um grupo de trabalho para estudar o cumprimento de uma recomendação pontual da CIDH no Estado de São Paulo; d) uma proposta de decreto legislativo para auferir status de emenda constitucional ao Pacto de São José da Costa Rica; e e) três projetos de lei que visam caracterizar as sentenças condenatórias, no que diz respeito ao quantum indenizatório, como títulos executivos judiciais. Em quase trinta anos da ratificação da Convenção, e depois de diversas violações da mesma, as poucas criações legislativas se limitam a dispor da indenização das vítimas, diferenciando-se somente o Decreto $\mathrm{n}^{\mathrm{o}} 51.678 / 07$, que institui um grupo de estudos.

\section{INTERPRETAÇÃO DOS DADOS À LUZ DO MARCO TEÓRICO}

Ao consultar manuais de Direito voltados ao Direito Internacional Público, como "Manual de Direito Internacional Público" (ACCIOLY; NASCIMENTO E SILVA; CASELLA, 2012); “Curso de Direito Internacional Público" (MAZZUOLI, 2018); e "Direito Internacional Público: curso elementar" (REZEK, 2014), percebe-se que a doutrina nacional compreende a matéria como a área do Direito que regulamentaria as relações entre Estados ${ }^{7}$. Ocorre que a visão apresentada pelos manuais não pode ser considerada científica ou crítica, uma vez que não parte de um método científico, porém da autoridade de quem escreve a obra e de reverência feita a outros autores que comungam de seus posicionamentos doutrinários, quando muito se limitando a uma síntese entre ideias e opiniões (DANTAS, 2017). Inclusive, a produção acadêmica vinculada aos cursos de Direito padece de vícios presentes em obras manualísticas, tais quais anacronismo e combinação de marcos teóricos conflitantes, não servindo de base para uma pesquisa mais aprofundada (OLIVEIRA, 2016).

A assertiva de que o Direito Internacional Público serviria para regulamentar a relação entre Estados e outras pessoas jurídicas de direito internacional não está completamente errada, porém se subtrai de algumas nuances. A questão que demonstra a incompletude dessa afirmação

\footnotetext{
${ }^{7}$ E em menor grau, de Estados com Organizações Internacionais e Indivíduos.
} 
é a própria regulação das relações entre o Estado e o indivíduo, ou seja, o sujeito de direito, que agora o é tanto nacional quanto internacionalmente (TRINDADE, 2013). A proeminência do indivíduo no Direito Internacional Público é muito exemplificada dentro da esfera dos Direitos Humanos, em que o Estado deve responder pelas suas violações perante a vítima, todavia a Corte Internacional de Justiça também já teve a oportunidade de expor que o indivíduo possui direitos na esfera do Direito Internacional Público, como se nota do julgamento do caso da Jurisdição das Cortes de Dantzig (MCCORQUODALE, 2003).

Disso, é possível se perguntar qual seria a função do Direito Internacional Público. Koskenniemi (2003) responde que serviria para 1) reproduzir as práticas, valores e preferências daqueles Estados em posição de dominância; 2) repercutir abusos e violência praticados pelas potências contra aqueles mais fracos; 3) codificar a Lei Internacional e as práticas internacionais, servindo como um elemento de segurança jurídica; e 4) representar uma promessa de justiça. A avaliação de Koskenniemi, apesar de crítica, falha em compreender o Direito ${ }^{8}$ dentro da sociabilidade capitalista, confundindo causa com consequência:

Contudo, a história e as políticas da ONU, enquanto, talvez, altamente condutivas do imperialismo, não são fundamentalmente constitutivas dele. $\mathrm{O}$ capitalismo moderno é um sistema imperialista e jurídico. As formas estruturantes do Direito Internacional são formas estruturantes do capitalismo global e, consequentemente, do imperialismo. E é esse o motivo que não é meramente propagandístico que os EUA e outras potências imperialistas configurem suas ações em termos jurídicos (MIÉVILLE, 2005, p. 290, tradução minha) $)^{9}$.

Com efeito, o Direito, de modo geral, é estruturante do capitalismo. Porém, afirmar isso é incompleto. Pachukanis explica que a forma jurídica, ou seja, aquilo que é revestido pelo Direito, dentro da sociabilidade capitalista, deriva da forma mercadoria. Isso significa que, antes de tudo, o Direito é construído para movimentar as mercadorias dentro de um mercado. Igualmente, aponta o jurista soviético, o Direito serve para legitimar essa movimentação de mercadorias, bem como o domínio dos meios de produção que estruturam o mercado. Essa dinâmica pode ser representada, principalmente, pela criação do conceito de "sujeito de direito", a quem são atribuídas uma igualdade e uma liberdade formal. O contrato de trabalho seria o exemplo mais claro através do qual o trabalhador aliena "livremente" sua força de trabalho como mercadoria

\footnotetext{
${ }^{8}$ Seja ele Internacional ou Nacional.

${ }^{9}$ Original: "However, the history and politics of the UN, while perhaps highly conducive to imperialism, are not fundamentally constitutive of it. Modern capitalism is an imperialist system, and a juridical one. International law's constituent forms are constituent forms of global capitalism, and therefore of imperialism. This is why it is not merely propagandist that the US and other imperialist powers frame their actions in juridical terms."
} 
Composição, Revista de Ciências Sociais da Universidade Federal de Mato Grosso do Sul. ISSN: 1983-3784. v 2, n 25 - p 30-43. Jul-dez 2021. Doi: https://doi.org/10.36066/compcs.v2i25.13949

para o burguês. Isso somente é possível a partir da construção da ideia do "sujeito de direito" (PACHUKANIS, 1988).

Antes do estabelecimento da forma jurídica no seio da reprodução da sociabilidade capitalista, não se poderia falar em propriamente em Direito. Por consequência, também não haveria o sujeito de direito. Previamente à economia capitalista, a economia escravista ilustra bem o conceito: a) o escravo pertencia ao seu senhor e era compreendido como coisa; b) o senhor possuía direitos, mas advindos diretamente da sua força política, econômica ou religiosa, não mediados através da figura do Estado; e c) os indivíduos que não se enquadravam nessa relação senhor-escravo, não eram iguais e livres perante a lei, como, por exemplo, perante os senhores de escravos. Essa evolução ${ }^{10}$ do conceito do "sujeito de direito" pode ser vista nas gerações de direitos (ou de garantias) fundamentais, começando pelas liberdades e pelas questões de igualdades tidas como mais básicas, como as liberdades de credo e de expressão, avançando para matérias mais complexas, como o direito à saúde do trabalhador e ao meio ambiente saudável (GRILLO, 2017).

Os Direitos Humanos ${ }^{11}$ não se afastam desse esquema teórico. No caso, são uma expressão amplificada do "sujeito de direito". Inclusive, sequer se cogitaria a ideia de Direitos Humanos sem um sujeito a quem se pudesse atribuí-los (MASCARO, 2017). Não obstante serem uma arma crítica e jurídica, contribuem, às vezes em maior, às vezes em menor grau, à dinâmica da reprodução do capitalismo:

A institucionalização dos direitos humanos advém de fontes distintas. Seu núcleo central é o reflexo da própria dinâmica da reprodução do capital, e é por tal razão que determinados direitos humanos são estruturais. Sua periferia, os direitos políticos, sociais e coletivos, é incidental. Em momentos de crise, são apenas os movimentos dos grupos explorados - e, eventualmente, algum espaço jurídico estatal - que garantem os direitos humanos incidentais; por sua vez, os direitos humanos estruturais são garantidos pela própria dinâmica do capitalismo (MASCARO, 2017, p. 121).

A essa dinâmica entre sujeito de direito e reprodução do capital falta um ponto importante: o Estado. Ainda nos ensinamentos de Alysson Mascaro, da forma mercadoria não advém somente o Direito como também a forma política, o Estado. Separa-se, portanto, do burguês o poder direto sobre o trabalhador, atribuindo ao Estado, como um terceiro imparcial. Ressalta-se que, à primeira vista, o Estado pode contrariar os interesses capitalistas, como

\footnotetext{
${ }^{10}$ Evolução no sentido amplo da palavra, não como um adjetivo de algo superior.

${ }^{11}$ Aqui tidos como um enunciado ético do mínimo que deveria ser assegurado a uma pessoa (SEN, 2011).
} 
estabelecendo normas trabalhistas ou possibilitando o voto universal, mas em última instância, quando o capital estiver ameaçado, articula-se da maneira que for preciso para sustentá-lo (MASCARO, 2013).

Sendo o Brasil um país capitalista e o Legislativo componente do Estado brasileiro, esse, então, não pode se eximir de participar da dinâmica de reprodução da sociabilidade capitalista. As propostas de legislação e legislação vigente, inclusive, apontam nessa direção.

Dos dados encontrados, depreende-se que, exceto o Decreto $\mathrm{n}^{\mathrm{o}} 51.678 / 07$, todos os projetos de lei e a legislação vigente versam indenizações das vítimas de violações de direitos humanos perpetradas pelo Brasil. Isso demonstra a monetização do sofrimento e da vida das pessoas envolvidas, atribuindo valor a algo que não se poderia quantificar. Todavia, essa é a dinâmica do capitalismo (MASCARO, 2013). Por outro lado, as sentenças condenatórias da Corte IDH não se limitam a indenizações em dinheiro, como se pode ver do Caso Herzog:

O Estado deve reiniciar, com a devida diligência, a investigação e o processo penal cabíveis, pelos fatos ocorridos em 25 de outubro de 1975, para identificar, processar e, caso seja pertinente, punir os responsáveis pela tortura e morte de Vladimir Herzog, em atenção ao caráter de crime contra a humanidade desses fatos e às respectivas consequências jurídicas para o Direito Internacional, nos termos dos parágrafos 371 e 372 da presente Sentença. Em especial, o Estado deverá observar as normas e requisitos estabelecidos no parágrafo 372 da presente Sentença (CORTE IDH, 2018, p. 103).

Como apontado, o Caso Herzog não é a primeira condenação brasileira pela Corte IDH. Conclui-se que as indenizações advindas das condenações anteriores não vêm desencorajando o Brasil a parar com as violações de Direitos Humanos, somente servindo como um preço a ser pago por elas. Além de serem violados os direitos humanos das vítimas, viola-se a obrigação internacional de respeitar a Convenção Americana de Direitos Humanos, devidamente ratificada, a jurisdição da Corte IDH, devidamente reconhecida, e a autoridade da CIDH, igualmente reputada válida.

\section{CONCLUSÃO}

O Brasil foi condenado diversas vezes pela Corte IDH e firmou acordos perante a CIDH em razão de violações à Convenção Americana de Direitos Humanos. Essa, no que lhe toca, foi ratificada em 1992, ao passo que a jurisdição da Corte IDH, reconhecida em 2002 para fatos 
posteriores a 10 de dezembro de 1998. Assim, depreende-se que não há motivos jurídicos para negar vigência aos direitos previstos pelo Pacto de São José da Costa Rica nem às sentenças da Corte IDH ou acordos da CIDH.

Não obstante, o país não cumpriu por completo nenhuma sentença ou acordo apresentados. Quando muito, pagou indenizações às vítimas ou aos seus sucessores. O Legislativo, que é o Poder que teria a possibilidade de estabelecer diretrizes e legislar acerca da questão, cuidou somente das indenizações. Ou seja, de $1992^{12}$ até 2020, focou-se em procedimentos sobre como as vítimas seriam compensadas pelo seu sofrimento. Em nenhum projeto de legislação ou legislação vigente relacionados à $\mathrm{CADH}$, houve cuidado para prevenção das violações a direitos humanos.

Haveria diversas maneiras de abordar a questão, desde estabelecer a previsão legal do dever de criar comissões temáticas para estudar mecanismos de respostas em caso de condenações na Corte IDH até impor auditorias internas vinculadas a relatórios da CIDH. Ocorre que o Direito, nacional ou internacional, não é concebido, em primeiro lugar, como uma ferramenta para proteção do indivíduo, mas como estrutura e estruturante da reprodução capitalista. Então, a indenização à vítima é muito mais vantajosa, por ser prática e econômica, do que algum mecanismo legal que necessitaria de um orçamento adequado para proceder à prevenção dessas violações de direitos humanos.

Dessa maneira, percebe-se que houve vontade política do Legislativo para regulamentar a Convenção Americana de Direitos Humanos. Todavia, limitou-se a procedimentos referentes às indenizações impostas pelas sentenças condenatórias da Corte IDH, priorizando a indenização no lugar da prevenção.

\section{Referências}

ACCIOLY, Hildebrando; NASCIMENTO E SILVA, G.E. do; CASELLA, Paulo Borba. Manual de Direito Internacional Público. 20ª ed. São Paulo: Saraiva. 2012.

BERNARDI, Bruno Boti. O Sistema Interamericano de Direitos Humanos e o caso da guerrilha do Araguaia: impactos no Brasil. Revista Brasileira de Ciência Política, Brasília, n. 22, p. 49-92, jan./abr. 2017. Disponível em: http://www.scielo.br/pdf/rbcpol/n22/2178-4884-rbcpol-22-00049.pdf. Acesso em: 29 jan. 2021.

\footnotetext{
${ }^{12}$ Ou de 1998, a depender do critério a ser utilizado, se ratificação da Convenção, se reconhecimento da jurisdição da Corte IDH.
} 
BRASIL. Assembléia Legislativa do Estado de São Paulo. Decreto $\mathbf{n}^{\mathbf{0}} \mathbf{5 0 . 0 6 7}$, de 29 de setembro de 2005a. Dispõe sobre a representação do Estado nos assuntos da Comissão Interamericana de Direitos Humanos. Disponível em:

$<$ https://www.al.sp.gov.br/norma/?id=58120>. Acesso em: 18 fev. 2021.

BRASIL. Assembleia Legislativa do Estado de São Paulo. Decreto n ${ }^{0}$ 51.678, de 20 de março de 2007a. Institui Grupo de Trabalho para estudar o cumprimento das Recomendações oriundas do Relatório n ${ }^{0}$ 66, de 2006, da Comissão Interamericana de Direitos Humanos. Disponível em: $<$ https://www.al.sp.gov.br/norma/71100>. Acesso em: 18 fev. 2021.

BRASIL. Câmara dos Deputados. Diário da Câmara dos Deputados. Ano 60. № 065. Publicado em: 03 mai. 2005e. Disponível em:

$<$ http://imagem.camara.gov.br/Imagem/d/pdf/DCD03MAI2005.pdf\#page=17>. Acesso em: 18 fev. 2021.

BRASIL. Câmara dos Deputados. Projeto de decreto legislativo no 1.595 de 2005d. Faz equivaler à Emenda Constitucional a Convenção Americana sobre Direitos Humanos (Pacto de São José da Costa Rica), de 22 de novembro de 1969. Disponível em:

$<$ https://www.camara.leg.br/proposicoesWeb/fichadetramitacao?idProposicao=280294>. Acesso em: 18 fev. 2021.

BRASIL. Câmara dos Deputados. Projeto de lei $\mathbf{n}^{\mathbf{0}}$ 153, de dezembro de 2019a. Dispõe sobre os efeitos jurídicos das decisões da Comissão Interamericana de Direitos Humanos e da Corte Interamericana de Direitos Humanos e dá outras providências. Disponível em:

$<$ https://www.camara.leg.br/proposicoesWeb/prop_mostrarintegra?codteor=1855142\&filename $=$ PL+153/2020>. Acesso em: 18 fev. 2021.

BRASIL. Constituição Federal de 1988. Disponível em:

$<$ http://www.planalto.gov.br/ccivil_03/constituicao/constituicao.htm>. Acesso em: 10 fev. 2021.

BRASIL. Decreto $n^{0}$ 4.463, de 8 de novembro de 1998. Promulga a Declaração de

Reconhecimento da Competência Obrigatória da Corte Interamericana de Direitos Humanos, sob reserva de reciprocidade, em consonância com o art. 62 da Convenção Americana sobre Direitos Humanos (Pacto de São José), de 22 de novembro de 1969. Disponível em:

$<$ http://www.planalto.gov.br/ccivil_03/decreto/2002/d4463.htm>. Acesso em: 18 fev. 2021.

BRASIL. Decreto n ${ }^{0}$ 5.611, de 12 de dezembro de 2005b. Autoriza a Secretaria Especial dos Direitos Humanos da Presidência da República a dar cumprimento às recomendações da Comissão Interamericana de Direitos Humanos, e dá outras providências. Disponível em: $<$ http://www.planalto.gov.br/ccivil_03/_ato2004-2006/2005/decreto/D5611.htm>. Acesso em: 18 fev. 2021.

BRASIL. Decreto n ${ }^{0}$ 5.619, de 14 de dezembro de 2005c. Autoriza a Secretaria Especial de Direitos Humanos da Presidência da República a concluir Acordo de Composição Amistosa com vistas ao encerramento dos casos $n^{0} \mathrm{~s} 12.426$ e 12.427 em trâmite perante a Comissão Interamericana de Direitos Humanos. Disponível em:

$<$ http://www.planalto.gov.br/ccivil_03/_ato2004-2006/2005/decreto/D5619.htm>. Acesso em: 18 fev. 2021. 
BRASIL. Decreto $\mathbf{n}^{\mathbf{0}} \mathbf{6 . 1 8 5}$, de 13 de agosto de 2007b. Autoriza a Secretaria Especial dos Direitos Humanos da Presidência da República a dar cumprimento à sentença exarada pela Corte Interamericana de Direitos Humanos. Disponível em:

$<$ http://www.planalto.gov.br/ccivil_03/_Ato2007-2010/2007/Decreto/D6185.htm\#: :text=DECR ETO\%20N\%C2\%BA\%206.185\%2C\%20DE\%2013,Corte\%20Interamericana\%20de\%20Direitos \%20Humanos. >. Acesso em: 18 fev. 2021.

BRASIL. Decreto no 678, de 6 de novembro de 1992. Promulga a Convenção Americana sobre Direitos Humanos (Pacto de São José da Costa Rica), de 22 de novembro de 1969. Disponível em: <http://www.planalto.gov.br/ccivil_03/decreto/D0678.htm>. Acesso em: 10 fev. 2021.

BRASIL. Decreto $\mathbf{n}^{\circ}$ 7.158, de 20 de abril de 2010a. Autoriza a Secretaria de Direitos Humanos da Presidência da República a dar cumprimento à sentença exarada pela Corte Interamericana de Direitos Humanos. Disponível em:

$<$ http://www.planalto.gov.br/ccivil_03/_ato2007-2010/2010/decreto/D7158.htm\#: :text=DECRE TO\%20N\%C2\%BA\%207.158\%2C\%20DE\%2020,Corte\%20Interamericana\%20de\%20Direitos \%20Humanos.>. Acesso em: 18 fev. 2021.

BRASIL. Decreto $\mathbf{n}^{\mathbf{0}} \mathbf{7 . 3 0 7}$, de 22 de Setembro de 2010b. Autoriza a Secretaria de Direitos Humanos da Presidência da República a dar cumprimento à sentença exarada pela Corte Interamericana de Direitos Humanos. Disponível em:

$<$ https://pesquisa.in.gov.br/imprensa/jsp/visualiza/index.jsp?jornal $=1 \&$ pagina $=10 \&$ data $=23 / 09 / 2$ 010>. Acesso em: 10 fev. 2021.

BRASIL. Senado Federal. Projeto de Lei do Senado n⿳ 220, de 2016. Dispõe sobre o cumprimento das decisões da Comissão Interamericana de Direitos Humanos e das sentenças da Corte Interamericana de Direitos Humanos. Disponível em:

$<$ https://legis.senado.leg.br/sdleg-getter/documento?dm=3475176\&ts=1613657551778\&disposit ion=inline $>$. Acesso em: 18 fev. 2021.

BRASIL. Senado Federal. Projeto de Lei do Senado, $\mathbf{n}^{\mathbf{0}} \mathbf{4 2 0}$, de 2009. Altera a Lei $\mathrm{n}^{\circ}$ 5.869, de 11 de janeiro de 1973 (Código de Processo Civil), para incluir entre os títulos executivos judiciais a sentença proferica pela Corte Interamericana de Direitos Humanos, bem como para disciplinar procedimento para seu cumprimento. Disponível em:

$<$ https://legis.senado.leg.br/sdleg-getter/documento?dm=4284541\&ts=1593906521361\&disposit ion=inline $>$. Acesso em: 18 fev. 2021.

BRASIL. Tribunal Regional do Trabalho da Quarta Região (2 $2^{\text {a }}$ Turma). Recurso ordinário no 0021017-87.2018.5.04.0014. Relator: Desembargador Marcelo José Ferlin D’Ambroso.

Recorrente: SMTUR - Viagens e Turismo LDTA-ME. Recorrido: Elisiane Maria Silva de Souza. Julgamento: 12 jun. 2019b. Disponível em:

$<$ https://www.trt4.jus.br/pesquisas/rest/cache/acordao/pje/Pc0-79IkpGyRctYHAlSZWg?>. Acesso em: 18 fev. 2021.

CORTE INTERAMERICANA DE DIREITOS HUMANOS (CORTE IDH). Caso Herzog e Outros Vs. Brasil. Presidente: Eduardo Ferrer Mac-Gregor Poisot. Vice-Presidente: Eduardo Vio Grossi. Juízes: Humberto Antonio Sierra Porto Eugenio Raúl Zaffaroni; Elizabeth Odio 
Benito; e L. Patricio Pazmiño Freire. Sentença de 15 de março de 2018. Disponível em: $<$ https://www.corteidh.or.cr/docs/casos/articulos/seriec_353_por.pdf $>$. Acesso em: 27 fev. 2021.

DANTAS, Marcus Eduardo de Carvalho. Dogmática "opinativa": o exemplo da função social da propriedade. Revista Direito GV, São Paulo, v. 13, n. 3, pp. 769-795, set./dez. 2017.

Disponível em: <http://www.scielo.br/pdf/rdgv/v13n3/1808-2432-rdgv-13-03-0769.pdf > . Acesso em: 02 mar. 2021.

FREIRE, Nilcéa. Exposição de Motivos nº 016 - SPM/PR. Brasília, 16 de novembro de 2004. Projeto de Lei Maria da Penha. 2004. Disponível em:

$<$ https://www.camara.leg.br/proposicoesWeb/prop_mostrarintegra;jsessionid=node0imj1lg99ff3h kl3nsnndeg8b1070396. node0? codteor $=256085 \&$ filename $=$ Tramitacao-PL $+4559 / 2004>$. Acesso em: 10 fev. 2021.

GALLO, Carlos Artur. Um acerto de contas com o passado: crimes da ditadura, "Leis de impunidade" e decisões das Supremas Cortes no Brasil e na Argentina. Curitiba: Appris. 2018.

GRILLO, Marcelo Gomes Franco. Direito Processual e capitalismo. São Paulo: Outras expressões. 2017.

KRAUSS, Peter; LIMA, João; LIMA, Davi. Destaques LexML. In: Portal do Projeto LexML. Última modificação em: 23 dez. 2016. Disponível em:

$<$ https://projeto.lexml.gov.br/documentacao/destaques-lexml\#o-que-lexml $>$. Acesso em: 18 fev. 2021.

KOSKENNIEMI, Martii. What is International Law for? In: EVANS, Malcolm D. International Law. 1st Edition. Oxford: Oxford University Press. 2003.

MASCARO, Alysson Leandro. Direitos Humanos: uma crítica marxista. In: Lua Nova, São Paulo, n. 101, pp. 109-137, 2017. DOI: http://dx.doi.org/10.1590/0102-109137/101. Disponível em: <http://www.scielo.br/pdf/ln/n101/1807-0175-ln-101-00109.pdf>. Acesso em: 29 jan. 2021.

MASCARO, Alysson Leandro. Estado e forma política. São Paulo: Boitempo. 2013.

MAZZUOLI, Valério de Oliveira. Curso de Direito Internacional Público. $11^{\text {a }}$ edição, revista, atualizada e ampliada. Rio de Janeiro: Forense. 2018.

MCCORQUADALE, Robert. The individual and the International Legal System. In: EVANS, Malcolm D. International Law. $1^{\text {st }}$ Edition. Oxford: Oxford University Press. 2003.

MIÉVILLE, China. Between equal rights : a Marxist theory of international law. Boston: Leiden. 2005.

NOLLKAEMPER, André. National Courts and the International Rule of Law. Oxford: University Press. 2011. 
PACHUKANIS, Evguiéni Bronislávovitch. Teoria Geral do Direito e Marxismo. São Paulo: Acadêmica. 1988.

OLIVEIRA, Luciano. Não fale do código de Hamurábi! A pesquisa sócio-jurídica na pós-graduação em direito. 2016. Disponível em: :

$<$ https://edisciplinas.usp.br/pluginfile.php/3932908/mod_resource/content/1/Hamurabi\%20Lucia no\%20Oliveira.pdf> . Acesso em: 11 fev. 2021.

ORGANIZAÇÃO DOS ESTADOS AMERICANOS (OEA). Seguimiento de decisiones de la CIDH en peticiones y casos individuales. 2021. Disponível em:

$<$ http://www.oas.org/es/cidh/actividades/seguimiento/casos.asp>. Acesso em: 10 fev. 2021.

RAMOS, André de Carvalho. Curso de Direitos Humanos. São Paulo: Saraiva. 2014.

REZEK, José Francisco. Direito internacional público: curso elementar. 15 ed. rev. e atual. São Paulo: Saraiva. 2014.

SEN, Amartya. A ideia de justiça. São Paulo: Schwarcz ltda. 2011.

TRINDADE, Antônio Augusto Cançado. Os tribunais internacionais contemporâneos. Brasília: FUNAG. 2013. Disponível em:

$<$ http://funag.gov.br/biblioteca/download/1018-tribunais-internacionais-contemporaneos.pdf $>$. Acesso em: 22 fev. 2021. 
Anexo

Conjunto de Dados - Marcírio Barcellos Gessinger

\begin{tabular}{|c|c|c|c|}
\hline Termo Procurado & Legislação & Ementa & Partido \\
\hline $\begin{array}{c}\text { Convenção } \\
\text { Americana de } \\
\text { Direitos Humanos }\end{array}$ & $\begin{array}{l}\text { Somente os textos da } \\
\text { própria Convenção }\end{array}$ & & \\
\hline $\begin{array}{l}\text { Corte Interamericana } \\
\text { de Direitos Humanos }\end{array}$ & $\begin{array}{c}\text { Decreto } \mathrm{n}^{\mathrm{o}} 7.307, \mathrm{de} \\
22 \text { de Setembro de } \\
2010\end{array}$ & $\begin{array}{c}\text { Autoriza a Secretaria } \\
\text { de Direitos Humanos } \\
\text { da Presidência da } \\
\text { República a dar } \\
\text { cumprimento à } \\
\text { sentença exarada } \\
\text { pela Corte } \\
\text { Interamericana de } \\
\text { Direitos Humanos - } \\
\text { CASO SÉTIMO } \\
\text { GARIBALDI }{ }^{1}\end{array}$ & PT - LULA \\
\hline $\begin{array}{l}\text { Corte Interamericana } \\
\text { de Direitos Humanos }\end{array}$ & $\begin{array}{l}\text { Decreto } n^{\circ} 7.158 \text {, de } \\
20 \text { de Abril de } 2010\end{array}$ & $\begin{array}{c}\text { Autoriza a Secretaria } \\
\text { de Direitos Humanos } \\
\text { da Presidência da } \\
\text { República a dar } \\
\text { cumprimento à } \\
\text { sentença exarada } \\
\text { pela Corte } \\
\text { Interamericana de } \\
\text { Direitos Humanos - } \\
\text { CASO ESCHER }^{2}\end{array}$ & PT - LULA \\
\hline $\begin{array}{l}\text { Corte Interamericana } \\
\text { de Direitos Humanos }\end{array}$ & $\begin{array}{c}\text { Decreto n }{ }^{\circ} 6.185 \text {, de } \\
13 \text { de Agosto de } \\
2007\end{array}$ & $\begin{array}{c}\text { Autoriza a Secretaria } \\
\text { Especial dos Direitos } \\
\text { Humanos da } \\
\text { Presidência da } \\
\text { República a dar } \\
\text { cumprimento à } \\
\text { sentença exarada } \\
\text { pela Corte } \\
\text { Interamericana de } \\
\text { Direitos Humanos - }\end{array}$ & PT - LULA \\
\hline
\end{tabular}

\footnotetext{
${ }^{1}$ Disponível em: <https://www.lexml.gov.br/urn/urn:lex:br:federal:decreto:2010-09-22;7307>. Acesso em: 12 mar. 2020.

${ }^{2}$ Disponível em: <https://www.lexml.gov.br/urn/urn:lex:br:federal:decreto:2010-04-20;7158>. Acesso em: 12 mar. 2020.
} 


\begin{tabular}{|c|c|c|c|}
\hline & & $\begin{array}{c}\text { DAMIÃO } \\
\text { XIMENES LOPES }\end{array}$ & \\
\hline $\begin{array}{c}\text { Comissão } \\
\text { Interamericana de } \\
\text { Direitos Humanos }\end{array}$ & $\begin{array}{c}\text { Decreto } n^{\circ} 50.067 \\
\text { de } 29 / 09 / 2005\end{array}$ & $\begin{array}{c}\text { Dispõe sobre a } \\
\text { representação do } \\
\text { Estado nos assuntos } \\
\text { da Comissão } \\
\text { Interamericana de } \\
\text { Direitos Humanos }\end{array}$ & $\begin{array}{l}\text { DEM - CLÁUDIO } \\
\text { LEMBO - } \\
\text { GOVERNO DE } \\
\text { SÃO PAULO }\end{array}$ \\
\hline $\begin{array}{l}\text { Comissão } \\
\text { Interamericana de } \\
\text { Direitos Humanos }\end{array}$ & $\begin{array}{l}\text { Decreto } \mathrm{n}^{0} 5.611 \text {, de } \\
12 \text { de Dezembro de } \\
2005\end{array}$ & $\begin{array}{c}\text { Autoriza a Secretaria } \\
\text { Especial dos Direitos } \\
\text { Humanos da } \\
\text { Presidência da } \\
\text { República a dar } \\
\text { cumprimento às } \\
\text { recomendações da } \\
\text { Comissão } \\
\text { Interamericana de } \\
\text { Direitos Humanos, e } \\
\text { dá outras } \\
\text { providências - } \\
\text { CASO OVELÁRIO } \\
\text { TAMES }\end{array}$ & PT - LULA \\
\hline $\begin{array}{l}\text { Comissão } \\
\text { Interamericana de } \\
\text { Direitos Humanos }\end{array}$ & $\begin{array}{c}\text { Decreto } n^{0} 5.619 \text {, de } \\
14 \text { de Dezembro de } \\
2005\end{array}$ & $\begin{array}{l}\text { Autoriza a Secretaria } \\
\text { Especial de Direitos } \\
\text { Humanos da } \\
\text { Presidência da } \\
\text { República a concluir } \\
\text { Acordo de } \\
\text { Composição } \\
\text { Amistosa com vistas } \\
\text { ao encerramento dos } \\
\text { casos nos } 12.426 \text { e } \\
12.427 \text { em trâmite } \\
\text { perante a Comissão } \\
\text { Interamericana de } \\
\text { Direitos Humanos - } \\
\text { CASO MENINOS }\end{array}$ & $\begin{array}{c}\text { PT - JOSÉ } \\
\text { ALENCAR GOMES } \\
\text { DA SILVA }\end{array}$ \\
\hline
\end{tabular}

\footnotetext{
${ }^{3}$ Disponível em:

<http://www.al.sp.gov.br/repositorio/legislacao/decreto/2005/decreto-50067-29.09.2005.html>. Acesso em: 13 mar. 2020.

${ }^{4}$ Disponível em:

<http://pesquisa.in.gov.br/imprensa/jsp/visualiza/index.jsp?jornal=1\&pagina=1\&data=13/12/2005> .

Acesso em: 13 mar. 2020.
} 


\begin{tabular}{|c|c|c|c|}
\hline & & $\begin{array}{l}\text { EMASCULADOS } \\
\text { DO MARANHÃO }\end{array}$ & \\
\hline $\begin{array}{c}\text { Comissão } \\
\text { Interamericana de } \\
\text { Direitos Humanos }\end{array}$ & $\begin{array}{c}\text { Decreto } n^{\circ} 51.678, \\
\text { de } 20 / 03 / 2007\end{array}$ & $\begin{array}{l}\text { Institui Grupo de } \\
\text { Trabalho para } \\
\text { estudar o } \\
\text { cumprimento das } \\
\text { Recomendações } \\
\text { oriundas do } \\
\text { Relatório n }{ }^{\circ} 66 \text {, de } \\
\text { 2006, da Comissão } \\
\text { Interamericana de } \\
\text { Direitos Humanos }\end{array}$ & $\begin{array}{c}\text { PSDB - JOSÉ } \\
\text { SERRA }\end{array}$ \\
\hline
\end{tabular}

\begin{tabular}{|c|c|c|c|}
\hline Termo Procurado & $\begin{array}{ll}\text { Proposta } & \text { de } \\
\text { legislação } & \end{array}$ & Ementa & Partido \\
\hline $\begin{array}{l}\text { Convenção } \\
\text { Americana de } \\
\text { Direitos Humanos }\end{array}$ & PDC 1595/2005 & $\begin{array}{l}\text { Faz equivaler à } \\
\text { Emenda } \\
\text { Constitucional a } \\
\text { Convenção Americana } \\
\text { sobre } \\
\text { Humanos (Pacto de } \\
\text { São José da Costa } \\
\text { Rica), de } 22 \text { de } \\
\text { novembro de } 1969^{7} .\end{array}$ & $\begin{array}{l}\text { INFORMAÇÃO } \\
\text { INDISPONÍVEL }\end{array}$ \\
\hline $\begin{array}{l}\text { Corte Interamericana } \\
\text { de Direitos Humanos }\end{array}$ & PL 153/2020 & $\begin{array}{l}\text { Dispõe sobre os efeitos } \\
\text { jurídicos das decisões }\end{array}$ & $\begin{array}{l}\text { INFORMAÇÃO } \\
\text { INDISPONÍVEL }\end{array}$ \\
\hline
\end{tabular}

\footnotetext{
${ }^{5}$ Disponível em:

<http://pesquisa.in.gov.br/imprensa/jsp/visualiza/index.jsp?jornal=1\&pagina=1\&data=15/12/2005>.

Acesso em: 13 mar. 2020.

${ }^{6}$ Disponível em: <https://www.al.sp.gov.br/norma/?id=71100>. Acesso em: 13 mar. 2020.

${ }^{7}$ Disponível em:

<https://www.lexml.gov.br/urn/urn:lex:br:camara.deputados:projeto.decreto.legislativo;pdc:2005-03-31; 1595>. Acesso em: 13 mar. 2020.
} 


\begin{tabular}{|c|c|c|c|}
\hline & & $\begin{array}{l}\text { da Comissão } \\
\text { Interamericana de } \\
\text { Direitos Humanos e da } \\
\text { Corte Interamericana } \\
\text { de Direitos Humanos e } \\
\text { dá outras providências. } \\
8\end{array}$ & \\
\hline $\begin{array}{l}\text { Corte Interamericana } \\
\text { de Direitos Humanos }\end{array}$ & PLS 220/2016 & $\begin{array}{l}\text { Dispõe sobre o } \\
\text { cumprimento das } \\
\text { decisões da Comissão } \\
\text { Interamericana de } \\
\text { Direitos Humanos e } \\
\text { das sentenças da Corte } \\
\text { Interamericana de } \\
\text { Direitos Humanos }{ }^{9} \text {. }\end{array}$ & $\begin{array}{l}\text { REDE - RANDOLFE } \\
\text { RODRIGUES }\end{array}$ \\
\hline $\begin{array}{l}\text { Corte Interamericana } \\
\text { de Direitos Humanos }\end{array}$ & PLS 420/2009 & $\begin{array}{l}\text { Altera a Lei } \mathrm{n}^{\circ} 5.869 \text {, } \\
\text { de } 11 \text { de janeiro de } \\
1973 \text { (Código de } \\
\text { Processo Civil), para } \\
\text { incluir entre os títulos } \\
\text { executivos judiciais a } \\
\text { sentença proferica pela } \\
\text { Corte Interamericana } \\
\text { de Direitos Humanos, } \\
\text { bem como para } \\
\text { disciplinar } \\
\text { procedimento para seu } \\
\text { cumprimento }{ }^{10} \text {. }\end{array}$ & $\begin{array}{l}\text { GARIBALDI ALVES } \\
\text { FILHO - MDB (antigo } \\
\text { PMDB) }\end{array}$ \\
\hline
\end{tabular}

\section{${ }^{8}$ Disponível em:}

$<$ https://www.camara.leg.br/proposicoesWeb/prop_mostrarintegra?codteor=1855142>. Acesso em: 13 mar. 2020.

${ }^{9}$ Disponível em: <https://legis.senado.leg.br/sdleg-getter/documento?dm=569347\&disposition=inline>. Acesso em: 13 mar. 2020.

${ }^{10}$ Disponível em:

<https://legis.senado.leg.br/sdleg-getter/documento?dm=627518\&disposition=inline>. Acesso em: 13 mar. 2020. 


\begin{tabular}{|c|c|c|c|}
\hline $\begin{array}{l}\text { Comissão } \\
\text { Interamericana de } \\
\text { Direitos Humanos }\end{array}$ & $\begin{array}{l}\mathrm{PL} \quad 153 / 2020 \\
\text { repete-se }\end{array}$ & $\begin{array}{l}\text { Dispõe sobre os efeitos } \\
\text { jurídicos das decisões } \\
\text { da Comissão } \\
\text { Interamericana de } \\
\text { Direitos Humanos e da } \\
\text { Corte Interamericana } \\
\text { de Direitos Humanos e } \\
\text { dá outras providências. } \\
11\end{array}$ & $\begin{array}{l}\text { REDE - RANDOLFE } \\
\text { RODRIGUES }\end{array}$ \\
\hline $\begin{array}{l}\text { Comissão } \\
\text { Interamericana de } \\
\text { Direitos Humanos }\end{array}$ & $\begin{array}{l}\text { PLS 220/2016 - } \\
\text { repete-se }\end{array}$ & $\begin{array}{l}\text { Dispõe sobre o } \\
\text { cumprimento das } \\
\text { decisões da Comissão } \\
\text { Interamericana de } \\
\text { Direitos Humanos e } \\
\text { das sentenças da Corte } \\
\text { Interamericana de } \\
\text { Direitos Humanos }^{12} \text {. }\end{array}$ & $\begin{array}{l}\text { INFORMAÇÃO } \\
\text { INDISPONÍVEL }\end{array}$ \\
\hline
\end{tabular}

Exceções: o próprio texto da Convenção e seus protocolos.

\footnotetext{
${ }^{11}$ Disponível em:

$<$ https://www.camara.leg.br/proposicoesWeb/prop_mostrarintegra?codteor=1855142>. Acesso em: 13 mar. 2020.

${ }^{12}$ Disponível em:

$<$ https://legis.senado.leg.br/sdleg-getter/documento?dm=569347\&disposition=inline>. Acesso em: 13 mar. 2020.
} 


\title{
O ânimo das massas e a psicologia do sujeito mutilado: Leon Trotsky e Theodor Adorno sobre o fascismo e a extrema direita
}

\section{The mood of the masses and the psychology of the mutilated subject: Leon Trotsky and Theodor Adorno on fascism and the far right}

\author{
Lucas Fiaschetti Estevez ${ }^{1}$
}

Recebido em 24/09/2021; aceito em 20/12/2021

\begin{abstract}
Resumo: Leon Trotsky e Theodor Adorno desenvolveram interpretações a respeito do fascismo que apresentam tanto divergências como pontos de contato. Enquanto o primeiro priorizava a dimensão política do fenômeno, o segundo se debruçou sobre o fascismo naquilo que ele mobilizava de sofrimento psíquico nas massas. O presente artigo busca comparar essas duas posições, principalmente no tocante ao status que a dimensão subjetiva e a questão da irracionalidade ocupam na obra dos autores.
\end{abstract}

Palavras-chave: Theodor Adorno, Leon Trotsky, fascismo.

Abstract: Leon Trotsky and Theodor Adorno have developed interpretations of fascism that have divergences but also points of contact. While the first prioritized the political dimension of the phenomenon, the second focused on fascism in what it mobilized of psychological suffering in the masses. This article aims to compare these two positions, mainly with regard to the status that the subjective dimension and the theme of irrationality occupy in the authors' work.

Keywords: Theodor Adorno, Leon Trotsky, fascism.

Figuras de relevo na plural trajetória do marxismo, Leon Trotsky (1879-1940) e Theodor Adorno (1903-1969) forneceram ao longo de suas obras distintas interpretações da extrema direita e do fascismo - as quais esse artigo tem por intenção comparar sob alguns aspectos específicos. Para isso, faz-se necessário explicitar algumas divergências de fundo que dizem respeito sobretudo (i) ao momento histórico diante do qual os autores se debruçaram, (ii) a tradição intelectual da qual faziam parte e, por fim, (iii) qual era o status da luta política e das possibilidades de transformação social em cada uma das formulações.

\footnotetext{
${ }^{1}$ Doutorando em Sociologia pela Universidade de São Paulo (PPGS/FFLCH). ORCID: 0000-0003-2963-1298. E-mail: lucas.estevez@usp.br. Este artigo é resultado de discussões empreendidas na disciplina de pós-graduação $A$ Crise Contemporânea: Capitalismo e Democracia, ministrada pelo Prof. Dr. André Singer e oferecida pelo Departamento de Ciência Política da Universidade de São Paulo no $1^{\circ}$ Semestre de 2021.
} 
Elaborada ao longo dos anos 1930, a interpretação trotskista do fascismo tinha diante de si os desdobramentos da crise do capitalismo e o recrudescimento do desemprego e da pauperização das classes pequeno-burguesas e proletárias, em especial na Alemanha. Para Trotsky, a crise que atingia o sistema revelava como as contradições do capitalismo tinham chegado a um ponto de não retorno (TROTSKY, 2018, p.75), no qual duas opções se abriam ao turbulento contexto de Weimar, a saber, a explosão do sistema pela via revolucionária ou a autodestruição pelo fascismo, este último oferecendo uma sobrevida à agonia de um sistema já "putrefato". A partir dessas circunstâncias históricas, a análise de Trotsky prioriza a dimensão da luta de classes, e se preocupa com a possibilidade do fascismo tomar o poder enquanto regime político.

Embora Adorno já estivesse atento desde as primeiras décadas do séc. XX ao fenômeno do fascismo, suas teses principais percorrem um horizonte mais alargado do que aquele de Trotsky. Como ideia central, o frankfurtiano toma o fascismo como um fenômeno intrínseco ao capitalismo. Embora tenha atingido sua forma mais desenvolvida no nazismo alemão e no fascismo italiano, Adorno nota como os pressupostos de sua reprodução perduraram na sociedade do pós-guerra (ADORNO, 2020a, p.54). Diante dos movimentos de extrema direita dos anos 1960, Adorno enfatiza como "a tendência de se entregar a políticas catastróficas, em vez de perseguir interesses racionais" (ADORNO, 2015a, p.71) continua latente nas sociedades democráticas. Abaixo da aparente estabilidade desse novo contexto, o autor aponta para a crescente ameaça do desemprego tecnológico e do rebaixamento social como uma das chaves explicativas do apoio recebido por tais movimentos, elemento também notado por Trotsky em sua caracterização da crise. Mesmo com este ponto em comum, Adorno opera uma mudança no nível da análise: perante a "sociedade administrada" do capitalismo do pós-guerra, o autoritarismo de extrema direita é encarado enquanto movimento, ou seja, enquanto índice de características imanentes de uma determinada forma social que persiste, a saber, o próprio capitalismo.

Mesmo que compartilhem muitos pressupostos de uma análise marxista da sociedade, os autores formulam suas concepções a respeito da extrema direita a partir de paradigmas antagônicos. Como pertencente à tradição do marxismo-leninismo, Trotsky norteia sua discussão a fim de atingir as consequências práticas de suas formulações abstratas e teóricas (TROTSKY, 1985, p.2). Nesse sentido, a resistência ao fascismo e a própria compreensão de sua natureza 
partem do paradigma da revolução proletária e da consciência de classe. Sua interpretação, nessa chave, se constitui como uma tentativa de explicar e corrigir os erros políticos e as estratégias equivocadas do Partido Comunista que afastaram de suas fileiras a pequena-burguesia e camadas do proletariado, que passaram a canalizar sua insatisfação no fascismo.

Desaparecido do horizonte da luta política no pós-guerra, o paradigma da revolução se mostra obsoleto para Adorno. Não só o autor, mas o próprio marxismo da Escola de Frankfurt se coloca diante do diagnóstico da interdição da práxis revolucionária e da integração do proletariado à sociedade de massas. Embora a luta de classes continue a organizar a sociedade do pós-guerra, sua estrutura torna-se opaca aos homens e o projeto no qual os oprimidos "poderiam unir-se como classe e pôr um fimm ao horror, parece não ter perspectiva diante da distribuição atual de impotência e poder" (ADORNO, 2020b, p.262). Estamos no reino da "invisibilidade das classes" e da "petrificação de suas relações", numa dita sociedade de indivíduos. Diante disso, deve-se investigar a permanência dos traços autoritários em uma sociedade que mobiliza os sujeitos não mais como integrantes de classes, mas como consumidores.

Cada um ao seu modo, Trotsky e Adorno respondem à questão do porquê as massas são suscetíveis à propaganda fascista - ou seja, investigam os condicionantes da efetividade social desse fenômeno. Porém, se o fascismo é incompatível com o interesse material dos mais desfavorecidos, o apoio recebido das camadas médias e subalternas deve ser explicado numa chave que vá além dos contornos da ação política racional e que ressalta os traços irracionais mobilizados por tais movimentos. Para isso, a análise política não pode dispensar a consideração da mediação dos indivíduos e de sua dimensão psicológica. Nas páginas seguintes, iremos nos atentar para como ambos os autores incorporaram a dimensão da subjetividade dos sujeitos em suas análises.

Preocupado com a natureza contrarrevolucionária do fascismo, Trotsky privilegia em sua interpretação a dimensão política do fenômeno. Frente à instabilidade da República de Weimar, o autor se propõe a analisar as determinações objetivas que estão em curso na luta de classes e no "estado de ânimo" de cada uma delas. Delineando o frágil equilíbrio de forças entre a grande burguesia, a pequena-burguesia e o proletariado, Trotsky entrevê como esses protagonistas da luta política, através de seus partidos e organizações, são atraídos para um ou outro destino político - o da revolução proletária ou da contra revolução fascista. A partir daí, o autor identifica como os erros sistemáticos da direção do Partido Comunista alemão, principalmente relativos à 
sua insistência na doutrina do social-fascismo e na decorrente impossibilidade de formação de uma frente única são, em grande medida, os principais equívocos que dão oportunidade para a grande burguesia cooptar tanto as camadas médias como setores do proletariado ao fascismo. Os erros de estratégia política estariam afastando os partidos operários de sua tarefa histórica, aquela de auxiliar a classe operária a adquirir sua consciência de classe (TROTSKY, 2018, p.98), transformando-a em uma classe para si. Submetidos à burocracia estalinista, os comunistas estariam fracassando em tentar se tornar a vanguarda autônoma do proletariado. Se uma mudança de postura não fosse adotada, o resultado seria uma separação cada vez maior "do partido e das massas e o enfraquecimento das organizações" (Idem, p.28).

Sob essa perspectiva, fica claro como Trotsky joga ao centro do debate a urgência do realinhamento das estratégias políticas dos comunistas. Um ano antes da ascensão de Adolf Hitler ao poder, o autor afirma que "a questão de perspectiva de vitória, nestas condições, concentra-se em três quartas partes na estratégia comunista" (Ibidem, p.260). Para o bolchevique, a adoção de uma estratégia política correta seria capaz de trazer aqueles atingidos pelo medo e pelo sofrimento social novamente para as fileiras do projeto revolucionário: se o partido realmente encarnar sua missão história, "então as massas acreditarão nele" (Ibidem, p.272). Se os destinos do proletariado são, em suma, os destinos do partido, caberia então à luta política transformar a passividade em ofensiva revolucionária. Entretanto, Trotsky nota que enquanto os partidos operários não mudarem suas posturas nem se unirem em torno de uma frente única, sua fragilidade e falta de direção não trará o apoio das massas. $\mathrm{O}$ sofrimento dos desfavorecidos é estrondoso e, hora ou outra, se agarrará a algum projeto político que se coloque como transformador:

O ânimo das massas operárias é pesado. Estão atormentadas pelo desemprego, pela miséria. Mas o que as inquieta mais é a confusão da direção, sua incoerência. Os operários compreendem que não se deve deixar Hitler chegar ao poder. Mas como? Ninguém sabe. A direção atrapalha em lugar de ajudar. Mas os operários querem lutar (Ibidem, p. 215).

O trecho acima revela como Trotsky também se atentava para a dimensão subjetiva do fenômeno, principalmente ao salientar o medo e o sofrimento social que atingia as massas pauperizadas e a pequena-burguesia. Para o autor, a resistência ao fascismo também dependeria de "uma série de elementos subjetivos", sobretudo aqueles que mobilizam nos indivíduos as ideias de "tradição, a iniciativa, a preparação da batalha" (TROTSKY, 1985, p.53). Assim, mesmo que se debruce sobre a conjuntura das forças políticas em curso, Trotsky inclui como um 
momento de sua interpretação a mediação dessa luta pelos próprios indivíduos. Segundo ele, os erros dos comunistas também decorrem da má-compreensão por parte de seus líderes a respeito da "psicologia das massas" (TROTSKY, 2018, p.114), o que favoreceria o alargamento do abismo entre o partido e as classes subalternas. Dessa forma, o sucesso do fascismo em angariar apoio entre as classes médias e até entre os proletários também é compreendido na chave do apelo psicológico que sua ideologia provoca nos indivíduos. Ao ocupar o vácuo deixado pelo Partido Comunista, "o fascismo tornou acessível a política nas profundezas da sociedade" (Idem, p.293) - ou seja, na subjetividade desses sujeitos abandonados.

Essa constatação reforça a ideia de que o fascismo se alimenta de uma crise social que coloca em xeque principalmente o padrão de vida da pequena-burguesia e a desloca "fora de seu equilíbrio" (Ibidem, p.32). Quando sua vida material é ameaçada e não há um partido revolucionário organizado capaz de canalizar tais demandas, a ânsia pela mudança social acaba por se transformar em "desespero contrarrevolucionário". Embora tenha como objetivo a destruição das organizações proletárias ${ }^{2}$ e seja o baluarte dos interesses da grande burguesia, o fascismo se apresenta paradoxalmente como o verdadeiro projeto revolucionário que livrará as massas de suas mazelas:

Por meio da agência fascista, a burguesia põe em movimento as massas da pequena burguesia enfurecida, os bandos de "sem-classe", os "lumpen-proletários" desmoralizados, todas essas inumeráveis existências humanas que o próprio capital financeiro levou ao desespero e à fúria (Ibidem, p.87).

Segundo Trotsky, a perspicácia dos fascistas em aliar "a demagogia anarquista aos objetivos conscientemente reacionários" (Ibidem, p.194) faz com que eles se apresentem como representantes de um movimento anti-sistêmico que oferece às massas impacientes, movidas por um sofrimento real, a imagem de uma revolução às avessas, na qual "a pequena burguesia perde a paciência e começa a ver nos trabalhadores revolucionários os culpados de sua própria miséria" (Ibidem, p.248). Como bem nota o autor, essa energia psíquica do descontentamento não pode ser menosprezada, já que "nenhuma classe pode viver muito tempo sem perspectivas e sem esperanças" (Ibidem, p.194). Ao pôr de pé as classes insatisfeitas umas contra as outras, principalmente os afetados pelo desemprego e pela proletarização, o fascismo une "todas as forças de frustração" (Ibidem, p.287) e engaja os desfavorecidos numa política diametralmente

\footnotetext{
${ }^{2}$ Embora esse prognóstico tenha se confirmado, vale lembrar que o regime nazista criou, logo em 1933, suas próprias organizações de massa. Dentre as mais importantes, destacam-se a Deutsche Arbeitsfront (Frente Alemã para o Trabalho), Kraft durch Freude (Força pela Alegria) e a Hitlerjugend (Juventude Hitlerista), as quais tiveram importante papel na integração das massas ao nacional-socialismo.
} 
oposta aos seus interesses materiais - e, nesse sentido, pode ser compreendido como um fenômeno de caráter irracional. Justamente por isso tais movimentos recorrem à narrativa de uma "mitologia" nacional e racial, a despeito de qualquer conteúdo histórico real. O conflito de classes deve necessariamente tornar-se secundário. Em um outro texto, Trotsky complementa:

Outro capítulo da história se abre quando se revelam as fraquezas dos oprimidos: heterogeneidade, insuficiência cultural, horizontes limitados. Cansadas, deprimidas, desiludidas, as massas perdem a confiança em si mesmas e cedem lugar a uma nova aristocracia. Neste período, os bolchevistas (os "trotskistas") encontram-se isolados das massas (TROTSKY, 1978, p.37).

Embora a análise de Trotsky reconheça o aspecto subjetivo do fascismo, deve-se ressaltar que seu diagnóstico é elaborado a partir do pressuposto do proletariado enquanto sujeito da revolução que, por diversos erros de natureza política que atingem os partidos e organizações de esquerda, têm se afastado de sua tarefa histórica. De forma distinta, Adorno se debruça sobre o fascismo num arco mais amplo, compreendendo o fenômeno além de sua forma política, ou seja, tomando-o também como a expressão de tendências imanentes ao capitalismo que persistem nas democracias liberais do pós-guerra. Com a integração das classes operárias à sociedade administrada, Adorno reelabora o diagnóstico em relação à mediação dos sujeitos nesse processo, ponto central de nossa investigação. Segundo o frankfurtiano, a eficiência dos líderes fascistas em encontrar apoio maciço nas massas não pode mais ser vista como, eminentemente, o resultado de erros de estratégia política. Na verdade, Adorno decompõe o fenômeno do fascismo a fim de entender sob um novo prisma o que leva milhões de indivíduos a apoiarem uma ideologia que, caso seja bem-sucedida, irá destruí-los. Se o fascismo não pode ser encarado em termos eminentemente racionais, deve-se então colocar no centro da investigação o sofrimento psíquico que mobiliza a massa. Nessa nova sociedade, os antigos paradigmas da luta política se desmancham, e a possibilidade de uma sociedade distinta degenera "na loucura do espelhamento infinito de si mesma" (ADORNO, 2020b, p.272).

É a partir dessa problemática que Adorno recorre à psicanálise freudiana ${ }^{3}$, não por um capricho teórico ou por uma interdisciplinaridade imposta a priori, mas sim como uma exigência imanente do próprio objeto. Segundo o autor, os aspectos psicológicos do fascismo são fundamentais justamente "por causa de seus objetivos irracionais e autoritários, que não podem ser alcançados por meio de convicções racionais, mas somente através do despertar habilidoso de

\footnotetext{
3 Em suas análises, Adorno é bastante tributário da interpretação freudiana exposta em Psicologia das Massas e análise do Eu (1921) e O mal-estar da civilização (1930).
} 
"uma parte da herança arcaica do sujeito" (ADORNO, 2015b, p.165). Entretanto, deve-se ressaltar que o uso de Adorno da psicologia não tem como objetivo tomar o aspecto psíquico dos indivíduos de forma dissociada do todo social. $\mathrm{Na}$ verdade, o autor quer explicitar o caráter social das próprias determinações psicológicas. Sua investigação não busca sociologizar a psique dos homens ou psicologizar a sociedade, mas reconhecer a contradição constitutiva entre as dimensões: ao mesmo tempo que se retroalimentam, não podem ser tomadas como um contínuo sem tensões. Se o desenvolvimento da individualidade no capitalismo tornou os indivíduos suscetíveis à propaganda fascista, deve-se então compreender a angústia que atinge tais grupos tomados pelo medo "das consequências dos desenvolvimentos gerais da sociedade" (ADORNO, 2020b, p.48). Para decifrar socialmente o fenômeno, é necessário portanto incluir como um momento da crítica dialética a análise da própria subjetividade, delineando o "novo tipo de sofrimento psicológico, bastante característico da era que, por razões socioeconômicas, testemunha o declínio do indivíduo" (ADORNO, 2015b, p.157). Entendido nesses termos, o sofrimento social é o resultado da reconciliação forçada entre a sociedade e o indivíduo, na qual o particular desaparece diante de um universal absoluto e autoritário (ADORNO, 2015a, p.133).

Ao enfatizar como o engajamento político do fascismo opera no nível da mobilização de afetos, medos e sofrimentos das massas, Adorno se aproxima de Trotsky ao compartilhar do diagnóstico que vê na crise social um terreno fértil para a extrema direita. Sem horizonte de melhora à vista, os indivíduos atingidos pelo desemprego tecnológico e pela ameaça castradora do rebaixamento de sua qualidade de vida passam a submergir nas massas integradas ao sistema, apresentando "atitudes primitivas contraditórias a seu comportamento racional normal" (ADORNO, 2015b, p.161). O desespero que atinge as massas encontra no fascismo não só uma possibilidade de luta, mas na própria figura do líder uma potente identificação psíquica, resultando numa submissão de caráter quase sadomasoquista ${ }^{4}$.

Por não poder enunciar seus verdadeiros interesses perante as massas, como o desmantelamento da seguridade social e a defesa dos interesses do grande capital, a propaganda fascista não recorre ao "auto interesse racional", mas sim "às necessidades emocionais"

\footnotetext{
${ }^{4}$ A importância do líder nos movimentos de extrema direita é central na interpretação de Adorno. Numa chave freudiana, o autor mostra como a efetividade do fascismo depende do estabelecimento de um vínculo artificial de natureza libidinal entre o líder e a massa. Dessa forma, os indivíduos colocam o líder no lugar ocupado pelo seu próprio Eu, e passam a se projetar e a se identificar nessa figura: "ao fazer do líder seu ideal, ele ama a si mesmo, por assim dizer, mas se livra das manchas de frustração e mal-estar que desfiguram a imagem de seu próprio eu empírico" (ADORNO, 2015b, p.169). Nesses termos, o fenômeno só pode ser entendido em sua dimensão coletiva, pois depende da relação do eu com algo externo a si próprio para se estabelecer enquanto vínculo.
} 
(ADORNO, 2019, p.88), atuando através de estilos discursivos de "natureza astuciosamente ilógica” (ADORNO, 2015c, p.138). Dessa forma, sua ideologia assume um caráter fragmentário e estereotípico, necessariamente construído a partir de constatações morais. Para criar o mínimo de coerência interna, escolhem-se inimigos - seja o comunismo, grupos étnico-raciais, grupos profissionais ou os imigrantes. A partir de truques psicológicos, os agitadores fascistas substituem as ideias pelas paixões, nas quais o irracional irrompe como uma "força integradora negativa” (ADORNO, 2015b, p.176). Além disso, a propaganda e a cultura massificada substituem o partido, o sindicato e as demais organizações que, anteriormente, constituíam o campo da luta e da formação das subjetividades das classes.

O fascínio exercido pelo fascismo nas massas é condicionado, em grande medida, pela impossibilidade socialmente determinada de apreensão, por parte dos sujeitos, da racionalidade econômica que rege a sociedade. Opaca e aparentemente sem direção, a ideologia reproduz a imagem de uma sociedade composta de indivíduos isolados que constroem o todo a partir da busca de seus interesses pessoais. Submetidos a uma situação contrária ao autoesclarecimento, os homens internalizam o medo de serem excluídos socioeconomicamente sem estabelecerem a lógica causal de sua penúria com o mecanismo da acumulação capitalista. Transformado numa segunda natureza dissociada do todo social (ADORNO, 2015a, p.77), o sofrimento passa a reproduzir em si mesmo o caráter irracional do movimento infindável do capital, contrário à realização das necessidades humanas e restrito ao progresso da técnica. Nessa dialética que toma os modos de comportamento como momentos da totalidade social, o indivíduo potencialmente fascista $^{5}$ é aquele que melhor reflete a penúria da sociedade. Longe de serem lunáticos, tais sujeitos são o mais claro exemplo do condicionamento autodestrutivo das subjetividades que engajam-se contra si próprias, num processo de coisificação das consciências que reflete uma postura apologética frente ao mundo social:

A sociedade atual, entretanto, é "totalitária" também no fato de nela os seres humanos como tais, talvez de forma mais abrangente do que antes, igualarem-se a energia do seu eu ao movimento da sociedade; de forma a impulsionar cegamente sua autoalienação até a imagem ilusória da igualdade entre o que são para si e o que são em si (Idem, p.106).

\footnotetext{
${ }^{5}$ Adorno e sua equipe realizaram nos Estados Unidos uma extensa pesquisa nos anos 1950, intitulada Estudos sobre a Personalidade Autoritária, a fim de identificar as determinações sociais e o perfil psicológico dos indivíduos potencialmente autoritários e de "tipo manipulador" nas sociedades democráticas. Neste trabalho, encontraram as seguintes características nesses sujeitos: convencionalismo, submissão autoritária, agressão autoritária, anti-intracepção, superstição e estereotipia, poder e "dureza", destrutividade, cinismo, desprezo pelo humano, projetividade e excessiva preocupação com questões sexuais (ADORNO, 2019, p.135).
} 
Nesse sentido, os indivíduos monadológicos só servem ao aparato como consumidores de mercadorias, de bens da indústria cultural e de projetos políticos autoritários. Dessa forma, sucumbem eles mesmos ao status de coisa intercambiável e abstrata. Diante da ameaça de pauperização e do desemprego tecnológico, os indivíduos compreendem sua situação como "potencialmente supérflua" (ADORNO, 2020a, p.47), sem lugar no processo de produção. Para Adorno, é deste desespero que a propaganda fascista se aproveita, fornecendo respostas fáceis e gratificações psicológicas. Através de sua fraseologia vaga, os demagogos fascistas prometem algo diferente do que "está aí" àqueles que não têm mais nada a perder (Idem, p.52). Adotando diferentes maneiras ao longo da história, esses movimentos apontam um novo caminho nacional (Make America), delineiam um futuro abstrato (great) e romantizam o passado (again) como única solução diante da miséria que atinge milhões. Na compreensão do autor, esses elementos revelam a natureza contraditória de tais movimentos, que ao mesmo tempo são anti-sistêmicos e conservadores, capazes de unir o apelo à ordem com o ataque ao existente. Entretanto, nem tudo que aí é mobilizado é falso. Justamente por se aproveitar das consequências econômicas desagregadoras do desenvolvimento da sociedade burguesa, a ideologia fascista não deve ser tomada como pura mentira e loucura:

[...] de modo algum todos os elementos dessa ideologia são simplesmente falsos, mas que também o verdadeiro entra a serviço de uma ideologia não verdadeira e que o truque essencial para resistir a isso consiste em denunciar o abuso da verdade pela inverdade (Ibidem, p.65).

Embora encontre apelo na psique dilacerada dos homens, cabe à crítica revelar a irracionalidade dessa política como uma necessidade intrínseca ao seu próprio funcionamento. Adorno nota que o fascismo inibe seus objetivos reais pois eles são, a princípio, indizíveis. Ao não apelar para sua meta final, a extrema direita se atém aos meios, ao desespero na mobilização dos afetos, tornando-se uma prática política sem conceito (Ibidem, p.67), um "sistema delirante" que só entende a linguagem da dominação. Caso postulasse uma prática política racionalmente orientada, ficaria evidente como esses extremismos "contradizem os interesses materiais de grande número daqueles que pretendem abarcar" (ADORNO, 2015b, p.184). É por causa dessa contradição que o fascismo explora a própria debilidade da subjetividade dos homens ao seu favor. Ao se dirigir àqueles que sofrem de "frustrações sem sentido", a propaganda toma os homens como “átomos sociais desindividualizados e pós-psicológicos” (Idem, p.187), como os 
"verdadeiros filhos da cultura de massa padronizada de hoje, em grande parte subtraídos de sua autonomia e espontaneidade" (Ibidem, p.184).

A partir dos pontos anteriormente expostos, buscamos delinear como Trotsky e Adorno abordaram não só os condicionantes da adesão de parcelas significativas das classes intermediárias e subalternas aos movimentos fascistas, como também os porquês do bloqueio das lutas emancipatórias mesmo diante da pauperização e da crise social. Embora difiram na ênfase dada à dimensão psicológica e política, ambos concordam em apontar que as tendências autoritárias presentes na sociedade não se explicam somente pelos erros das organizações, dos partidos e das demais instâncias da luta política progressista, mas também decorrem de como os indivíduos canalizam seu desespero e sofrimento social no fascismo.

Como salientamos anteriormente, o caráter irracional do fascismo, seja enquanto regime, seja enquanto movimento, se dá justamente pelo fato de seu projeto político representar o extremo oposto dos interesses das massas que o apoiam. Sobre esse ponto, podemos fazer uma última aproximação entre os pensadores aqui selecionados. Por não poder explicitar seus interesses econômicos e políticos de forma clara, tanto Adorno como Trotsky reconheceram a necessidade lógica do fascismo em insistir nos meios, e não nos fins de suas ações. Segundo Trotsky, uma práxis política que não explicita os fins de sua estratégia carece de uma justificação racional - a saber, não se presta à realização dos interesses históricos do proletariado. Se a luta comunista se justifica pelo seu fim, ou seja, pela supressão da dominação do homem pelo homem, o fascismo confessa a quem serve ao abstrair de suas metas. Para o autor, "quando dizemos que o fim justifica os meios, disto deriva para nós que o grande fim revolucionário repudia, entre estes meios, os procedimentos e os meios indignos que lançam uma parte da classe operária contra outra", como os movimentos fascistas "que prometem 'a felicidade das massas' sem a sua organização, substituindo-as pela adoração dos “chefes"” (TROTSKY, 1978, p.35).

Ao abstrair de um conteúdo racional, o fascismo dificilmente poderia ser descrito como um projeto movido por uma vontade de realização política, mas sim como uma lógica destrutiva que, nos termos de Adorno, se auto movimenta em busca da realização do desejo (ADORNO, 2015c, p.140). Se por um lado temos a irracionalidade dos fins, o frankfurtiano nota a exatidão da razão instrumental dos meios, numa "constelação de meios racionais e fins irracionais" que 
expressam as tendências aporéticas da própria civilização ocidental (ADORNO, 2020a, p.54). Ao ignorar a "finalidade geral da sociedade", a política é reduzida à dimensão da administração do existente, numa logística apurada dos meios que ignora seu fim inominável, como na postura de Adolf Eichmann diante das listas de nomes colocadas sobre sua escrivaninha.

Para se transformar numa potente arma política, a resistência ao fascismo deve atacar justamente todo o irracionalismo com uma verdade não ideológica. A construção de uma alternativa à barbárie deve propor novos meios, mas ir além - deve conquistar um engajamento coletivo em torno de fins claros e racionalmente orientados. Nessa chave, vale a pena retomar a citação feita por Trotsky da peça Franz von Sickingen, de Ferdinand Lassalle, ao insistir na urgência em se compreender a "interdependência orgânica entre meios e fins" (TROTSKY, 1978, p.36) na construção de um novo caminho de luta política. Por vezes, a arte desata melhor os nós do pensamento do que o conceito:

Não indiques apenas o fim, / mas mostra também o caminho/ porque o fim e o caminho/ estão tão unidos/ que um muda com o outro/ e com ele se move/ - e cada novo caminho/ revela um novo fim (LASSALLE, 1910, p.63) ${ }^{6}$.

\section{Referências}

ADORNO, Theodor. Sobre a relação entre sociologia e psicologia. In: Ensaios sobre Psicologia Social e Psicanálise. São Paulo: Ed. Unesp, 2015a.

ADORNO, Theodor. Teoria freudiana e o padrão da propaganda fascista. In: Ensaios sobre Psicologia Social e Psicanálise. São Paulo: Ed. Unesp, 2015 b.

ADORNO, Theodor. Antissemitismo e propaganda fascista. In: Ensaios sobre Psicologia Social e Psicanálise. São Paulo: Ed. Unesp, 2015c.

ADORNO, Theodor. Estudos sobre a personalidade autoritária. São Paulo: Ed. Unesp, 2019.

ADORNO, Theodor. Aspectos do novo radicalismo de direita. São Paulo: Ed. Unesp, 2020a.

ADORNO, Theodor. Reflexões sobre a teoria de classes. In: Crítica Marxista, n.50; p.259-273, 2020 b.

LASSALLE, Ferdinand. Franz von Sickingen: a tragedy in five acts. Nova York: New York Labor News Company, 1910.

TROTSKY, Leon. Moral e Revolução. Rio de Janeiro: Paz e Terra, 1978. Paginação do PDF, dispo. em: http://cstpsol.com/home/dl/Leon\%20Trotsky/Moral\%20e\%20Revolu\%C3\%A7\%C3\%A3o.pdf

\footnotetext{
${ }^{6}$ Tradução nossa. Na versão consultada, lê-se: Show not the goal, / But also show the path. So closely tangled/ On earth are path and goal, and each with th'other/ Their places ever change, and other paths forthwith/Another goal set up.
} 

n 25 - p 44-55. Jul-dez 2021. Doi: https://doi.org/10.36066/compcs.v2i25.14490

TROTSKY, Leon. A revolução permanente. São Paulo: Kairós Livraria Editora, 1985.

TROTSKY, Leon. Como esmagar o fascismo. São Paulo: Autonomia Literária, 2018. 